Article

\title{
High Catalytic Performance of Mn-Doped Ce-Zr Catalysts for Chlorobenzene Elimination
}

\author{
Lei Zhu ${ }^{1,2,3}, \mathrm{Xi} \mathrm{Li}^{2}$, Zhiying Liu ${ }^{2, *}$, Lin Yao ${ }^{2}$, Peng $\mathrm{Yu}^{2}$, Ping Wei ${ }^{1}$, Yanhua $\mathrm{Xu}^{2, *}$ and \\ Xingmao Jiang ${ }^{4}$ \\ 1 College of Biotechnology and Pharmaceutical Engineering, Nanjing Tech University, Nanjing 210009, China; \\ zhul_88@163.com (L.Z.); weiping@njtech.edu.cn (P.W.) \\ 2 School of Environmental Science and Engineering, Nanjing Tech University, Nanjing 210009, China; \\ lixi_26@163.com (X.L.); njtyaolin@163.com (L.Y.); yspong@163.com (P.Y.) \\ 3 National Supervision and Testing Center of Fine Chemicals, Taizhou 225300, China \\ 4 School of Chemical Engineering and Pharmacy, Wuhan Institute of Technology, Wuhan 430205, China; \\ jxm@wit.edu.cn \\ * Correspondence: zhiying555@njtech.edu.cn (Z.L.); yanhuaxu18@hotmail.com (Y.X); \\ Tel.: +86-025-8317-2333 (Z.L.); +86-025-5837-5606 (Y.X.)
}

Received: 11 March 2019; Accepted: 16 April 2019; Published: 1 May 2019

\begin{abstract}
Mn-Ce-Zr-O catalysts doped with varying Mn content were prepared and assessed for the catalytic combustion of chlorobenzene (CB). Nanosized MCZ-0.67 catalyst with amorphous phase exhibited a high and stable catalytic activity among the studied catalysts, achieving $90 \%$ CB conversion at $226^{\circ} \mathrm{C}$ and withstanding stability tests, including time-based stability and the successive influence of various operating conditions. Meanwhile, the MCZ-0.67 catalyst used showed good recyclability by calcination in air. Characterization results suggested that Mn doping played a dominant role in improving the catalytic performance, resulting in larger surface area, better redox properties and greater amounts of surface active oxygen. In addition, the introduction of $\mathrm{Zr}$ was also indispensable for maintaining the good catalytic performance of catalysts. Finally, trace amounts of polychlorinated by-products during CB oxidation were monitored and the oxidation process was discussed.
\end{abstract}

Keywords: $\mathrm{MnOx}-\mathrm{CeO}_{2}-\mathrm{ZrO}_{2}$; catalytic combustion; chlorobenzene; active oxygen; product analysis

\section{Introduction}

Chlorinated volatile organic compounds (CVOCs), widely used as solvents, additives and raw materials in industry, are considered serious hazards to human health and the environment owing to their high toxicity, volatility and durability [1,2]. It is therefore of great significance to effectively control the environmental emissions of these compounds. Compared with conventional thermal combustion (operating above $1000{ }^{\circ} \mathrm{C}$ ), catalytic combustion is a promising heterogeneous catalytic oxidation technology for the elimination of CVOCs due to its much lower energy consumption (operating below $550^{\circ} \mathrm{C}$ ) and limited secondary pollution (avoiding the production of $\mathrm{NO}_{\mathrm{x}}$ and dioxins) [3]. However, the development of this technology is dependent on the advent of high-performance catalysts, which are regarded as the crucial enablers in most chemical reaction processes [4].

To date, despite much research on various types of catalysts, including supported noble metals [5,6], transition metal oxides $[7,8]$ and zeolites $[9,10]$ for CVOCs elimination, the occurrence of chlorine poisoning, the mass production of polychlorinated by-products and the low selectivity of $\mathrm{HCl}$ remain "bottlenecks" for the practical application of such catalysts. Limited natural resources and their susceptibility to chlorine poisoning restrict the widespread use of noble metals [11] despite their excellent activity and selectivity. Similarly, coking and chlorination reactions readily occur in zeolite 
catalytic systems [7,12]. Conversely, transition metal oxides possess a better thermal stability, stronger anti-poisoning ability and lower cost, thus arousing widespread interest $[13,14]$. In recent years, ceria has been used as a good promoter for the activity and structure of transition metal oxides owing to its high oxygen storage capacity (OSC) and relatively easy redox cycle between $\mathrm{Ce}^{4+}$ and $\mathrm{Ce}^{3+}[15,16]$. Specifically, the redox capability and dispersity of transition metal oxides are modified along with the partial substitution of $\mathrm{Ce}^{4+}$ in the $\mathrm{CeO}_{2}$ lattice with metal ions. The resulting improvements in oxygen vacancy concentration and oxygen mobility contribute to the elimination of adsorbed chlorine species, and thus to the enhancement of catalytic activity and stability for CVOCs elimination [17].

Of the Ce-based transition metal oxides, a $\mathrm{CeO}_{2}-\mathrm{ZrO}_{2}$ solid solution, widely applied in the purification of vehicle exhaust [18], the selective catalytic reduction (SCR) of $\mathrm{NO}_{\mathrm{x}}$ [19] and the catalytic oxidation of VOCs [20], was found to exhibit a high OSC and thermal stability after the doping of a proper amount of $\mathrm{ZrO}_{2}$ into the $\mathrm{CeO}_{2}$ lattice. Gutiérrez-Ortiz et al. [21] prepared a series of $\mathrm{Ce}_{\mathrm{x}} \mathrm{Zr}_{1-\mathrm{x}} \mathrm{O}_{2}$ solid solutions for the elimination of chlorinated aliphatic hydrocarbons, and showed that the catalytic performance was dominated by the increased surface acidity and oxygen mobility following $\mathrm{Zr}$ doping. However, considerable amounts of $\mathrm{Cl}_{2}$ resulting from the oxidation of $\mathrm{HCl}$ (Deacon reaction) were detected during the oxidation of chlorinated reactants. Moreover, due to the relatively low redox ability of $\mathrm{ZrO}_{2}$, the high reaction temperature required for the elimination of CVOCs by $\mathrm{CeO}_{2}-\mathrm{ZrO}_{2}$ mixed oxide catalysts was unsatisfactory [22].

$\mathrm{MnO}_{\mathrm{x}}$ compounds are highly active due to their various labile oxygen species and high efficiency in reaction/oxidation cycles [23] and have been widely used in the catalytic removal of various pollutants, including benzene series [24], chlorinated aromatic hydrocarbons [25], nitrogen oxides [26] and aldehydes [27]. In particular, $\mathrm{MnO}_{\mathbf{x}}-\mathrm{CeO}_{2}$ solid solution, as an environment-friendly catalyst with high catalytic efficiency, has become the focus of research on multipurpose catalysts [28]. Nevertheless, in the elimination of CVOCs, despite the activity and chlorine resistance of $\mathrm{CeO}_{2}$ having been greatly improved by Mn doping, the achievement of a high and stable catalytic activity still requires higher reaction temperature [29,30]. In addition, trace amounts of polychlorinated by-products resulting from the incomplete oxidation of CVOCs need to be further monitored and assessed.

Considering the respective advantages of $\mathrm{MnO}_{\mathrm{x}}$ and $\mathrm{CeO}_{2}-\mathrm{ZrO}_{2}$ catalysts, $\mathrm{Mn}-\mathrm{Ce}-\mathrm{Zr}-\mathrm{O}$ ternary catalyst seems to have promising prospects in catalysis. Shen et al. [19] prepared a series of $\mathrm{Mn} / \mathrm{Ce}-\mathrm{Zr}$-based catalysts for the SCR of NO. Results showed that the molar ratio of Ce to Zr had a significant influence on the catalytic activity, and $\mathrm{MnO}_{\mathrm{x}} / \mathrm{Ce}_{0.5} \mathrm{Zr}_{0.5} \mathrm{O}_{2}$ catalyst possessed the best $\mathrm{NO}$ conversion. However, the influence of $\mathrm{Mn}$ doping on the catalytic performance of $\mathrm{CeO}_{2}-\mathrm{ZrO}_{2}$ catalysts has seldom been systematically studied, especially for the elimination of CVOCs. Herein, Mn-Ce-Zr-O catalysts doped with a varying Mn content were synthesized and used for the elimination of CB, which is a typical CVOCs model widely used in the evaluation of catalysts [31,32]. The physicochemical properties of the prepared catalysts were systematically assessed by various material characterization techniques. The successive influence of $C B$ concentration, space velocity and water vapor on $C B$ destruction was also assessed in the stability study. Moreover, trace amounts of organic by-products during CB oxidation were monitored and the oxidation process was discussed.

\section{Materials and Methods}

\subsection{Catalyst Preparation}

$\mathrm{Mn}-\mathrm{Ce}-\mathrm{Zr}-\mathrm{O}$ catalysts were synthesized by the sol-gel method as follows: stoichiometric amounts of $\mathrm{Mn}\left(\mathrm{NO}_{3}\right)_{2}$ (SCRC, $50 \mathrm{wt} \%$ solution), $\mathrm{Ce}\left(\mathrm{NO}_{3}\right)_{3} \cdot 6 \mathrm{H}_{2} \mathrm{O}(\mathrm{SCRC}, 99 \%), \mathrm{ZrO}\left(\mathrm{NO}_{3}\right)_{2} \cdot 5 \mathrm{H}_{2} \mathrm{O}$ (Aladdin, $99.5 \%$ ) and citric acid (SCRC, 99.5\%, citric acid/( $\mathrm{Mn}+\mathrm{Ce}+\mathrm{Zr})=0.3$, molar ratio) were dissolved in deionized water and slowly heated to $80^{\circ} \mathrm{C}$, maintaining this temperature with continuous vigorous stirring until gelation occurred. The obtained gel was dried overnight at $110{ }^{\circ} \mathrm{C}$ and then calcined in a muffle furnace at $200{ }^{\circ} \mathrm{C}$ for $2 \mathrm{~h}$ and further at $550{ }^{\circ} \mathrm{C}$ for $5 \mathrm{~h}$. The synthesized catalysts were denoted as MCZ-x $(x=0,0.33,0.50,0.67$ and 0.80$)$, where $x$ is the molar ratio of $\mathrm{Mn} /(\mathrm{Mn}+\mathrm{Ce}+\mathrm{Zr})$ and the 
molar ratio of $\mathrm{Ce} / \mathrm{Zr}$ was maintained as 1 . As a reference, a $\mathrm{Mn}_{0.67} \mathrm{Ce}_{0.33}$ catalyst (denoted as $\mathrm{MC}-0.67$ ) was also prepared by the same method described above. Before use, all synthesized catalysts were finally made into 40-60 mesh particles through pressing, crushing and sieving.

\subsection{Catalyst Characterization}

Powder X-ray diffraction (XRD) patterns were recorded on a D8-ADVANCE diffractometer (Bruker, Karlsruhe, Germany) equipped with $\mathrm{Cu} K \alpha$ radiation source $(\lambda=0.15418 \mathrm{~nm})$. The $2 \theta$ was measured from $20^{\circ}$ to $80^{\circ}$ at a scanning rate of $0.04^{\circ} \mathrm{min}^{-1}$.

$\mathrm{N}_{2}$ adsorption-desorption experiments were carried out on a Tristar II 3020 instrument (Micromeritics, Atlanta, USA) at $-196{ }^{\circ} \mathrm{C}$. Prior to measurements, catalysts were degassed at $200{ }^{\circ} \mathrm{C}$ under vacuum for $2 \mathrm{~h}$. The Brunauer-Emmett-Teller (BET) and Barrett-Joyner-Halenda (BJH) methods were employed for the calculation of specific surface area and pore-size distribution, respectively.

$\mathrm{H}_{2}$-temperature programmed reduction $\left(\mathrm{H}_{2}\right.$-TPR) tests were measured under a mixed stream of $\mathrm{H}_{2}(10 \mathrm{vol} \%)$ and $\mathrm{Ar}(90 \mathrm{vol} \%)$, and $100 \mathrm{mg}$ of the catalyst was tested in the range of $50-800{ }^{\circ} \mathrm{C}$ with a heating ramp of $10^{\circ} \mathrm{C} \mathrm{min}^{-1}$. During the tests, a thermal conductivity detector (TCD) was employed to monitor the consumed $\mathrm{H}_{2}$.

X-ray photoelectron spectroscopy (XPS) measurements were carried out on a PHI 5000 VersaProbe instrument (Ulvac-Phi, Chigasaki, Japan) equipped with $\mathrm{Al} \mathrm{K \alpha}(\mathrm{hv}=1486.6 \mathrm{eV})$ radiation source. Binding energies of the studied atoms were calibrated by $284.6 \mathrm{eV}$ of $\mathrm{C} 1 \mathrm{~s}$. The obtained spectra were deconvoluted by peak fitting using the Shirley background and Gaussian-Lorentzian function provided by the XPSPeak software.

$\mathrm{O}_{2}$-temperature programmed desorption $\left(\mathrm{O}_{2}-\mathrm{TPD}\right)$ tests were carried out on an Auto Chem II 2920 instrument (Micromeritics, Atlanta, USA), and $100 \mathrm{mg}$ of the catalyst was tested in the range of $50-700{ }^{\circ} \mathrm{C}$ under a He stream at a heating ramp of $10^{\circ} \mathrm{C} \mathrm{min}^{-1}$. During the tests, a TCD detector was employed to monitor the desorbed $\mathrm{O}_{2}$. Prior to measurements, catalysts were treated at $300{ }^{\circ} \mathrm{C}$ for $2 \mathrm{~h}$ under a He stream and then at $50{ }^{\circ} \mathrm{C}$ for $2 \mathrm{~h}$ under a mixed stream of $\mathrm{O}_{2}(5 \mathrm{vol} \%)$ and $\mathrm{He}(95 \mathrm{vol} \%)$.

Scanning electron microscopy (SEM) images were taken on a Hitachi S4800 apparatus.

Transmission electron microscopy (TEM) and scanning transmission electron microscopy (STEM) images were taken at a voltage of $200 \mathrm{kV}$ on a JEM-2100F microscope (JEOL, Akishima, Japan) equipped with an energy dispersive X-ray spectrometer (EDX). Powder catalysts were previously treated by dispersing them in ethanol and then depositing on carbon-coated copper grid.

\subsection{Catalytic Performance Evaluation}

Activity tests were carried out on a conventional fixed-bed microreactor. In each test, $200 \mathrm{mg}$ of the catalyst was packed in the middle of the quartz tube ( $4 \mathrm{~mm}$ i.d.). $\mathrm{N}_{2}$ was used to transport the $\mathrm{CB}$ vapor by bubbling the $\mathrm{CB}$ solution maintained at $40^{\circ} \mathrm{C}$. The reaction gas, consisting of $1000 \mathrm{ppm}$ $\mathrm{CB}$ and $21 \mathrm{vol} \% \mathrm{O}_{2}$, was obtained by mixing three gas streams of $\mathrm{CB}$ vapor, $\mathrm{O}_{2}$ and $\mathrm{N}_{2}$ (balance) in a mixer. All gas streams were accurately monitored by mass flowmeters and the gas hourly space velocity (GHSV) was set at a typical value of $20,000 \mathrm{~h}^{-1}$. A thermocouple was employed to control the reaction temperature in the range of $100-300^{\circ} \mathrm{C}$. At given temperatures, the exhaust gases were detected on-line using a gas chromatograph (FULI 9790) equipped with two flame ionization detectors (FID), one of which was used for the analysis of $\mathrm{CB}$ quantitatively and the other for the measurement of $\mathrm{CO}_{2}$ and $\mathrm{CO}$ by means of a methane-converting furnace (Ni catalyst). The concentrations of $\mathrm{HCl}$ and $\mathrm{Cl}_{2}$ were determined by bubbling the off-gas through a $0.0125 \mathrm{~mol} \mathrm{~L}^{-1} \mathrm{NaOH}$ solution for $30 \mathrm{~min}$. Ion chromatograph (Thermo Scientific ICS-900) was used to measure the concentration of $\mathrm{Cl}^{-}$and chemical titration with ferrous ammonium sulphate (FAS) using $N, N$-diethyl-p-phenylenediamine (DPD) as an indicator was employed to determine the concentration of $\mathrm{Cl}_{2}$ in the bubbled solution.

The stability experiments of the prepared catalysts were performed at $300{ }^{\circ} \mathrm{C}$ under the same evaluation conditions described above. The water vapor environment was obtained by bubbling the deionized water with a $\mathrm{N}_{2}$ stream. 
Assessment of the $\mathrm{CB}$ decomposition products was performed by using hexane to absorb the various gaseous organics in the off-gas for $30 \mathrm{~min}$. After concentration, the hexane was analyzed by a gas chromatography-mass spectrometer (GC-MS, Agilent 7890B-5977A) using a weak polar DB-5MS capillary column.

\section{Results and Discussion}

\subsection{X-ray Diffraction (XRD) Characterization and $\mathrm{N}_{2}$ Adsorption-Desorption Analysis}

XRD patterns of MCZ-x and MC-0.67 catalysts showed that the crystallinity of the prepared catalysts was significantly affected by Mn content (Figure 1). For the MCZ-x (x=0,0.33, 0.50) and MC-0.67 catalysts, only diffraction peaks corresponding to the cubic fluorite-like structure of $\mathrm{CeO}_{2}$ were observed, with the lattice parameters (Table 1) being smaller than $5.41 \AA$ of pure CeO 2 (JCPDS $\# 43-1002)$. Indeed, the ionic radii of $\mathrm{Mn}^{\mathrm{n}+}\left(\mathrm{Mn}^{2+}=0.083 \mathrm{~nm}, \mathrm{Mn}^{3+}=0.065 \mathrm{~nm}, \mathrm{Mn}^{4+}=0.053 \mathrm{~nm}\right)$ and $\mathrm{Zr}^{4+}(0.084 \mathrm{~nm})$ are both smaller than that of $\mathrm{Ce}^{4+}(0.097 \mathrm{~nm})[29,33]$. Thus, the shrinkage of $\mathrm{CeO}_{2}$ unit cell indicates that parts of $\mathrm{Ce}^{4+}$ ions in $\mathrm{CeO}_{2}$ lattice were replaced by $\mathrm{Mn}^{\mathrm{n}+}$ and $\mathrm{Zr}^{4+}$ ions to form a solid solution. Remaining Mn- and Zr-related oxides may be uniformly distributed on the surface of $\mathrm{CeO}_{2}$ in a poor crystalline state. At the $2 \theta$ range from $24^{\circ}$ to $40^{\circ}$, only a weak and widened peak was observed for the MCZ-0.67 catalyst, indicating that it exists in an amorphous state. With the further increase of Mn content, weak diffraction peaks indexed to $\mathrm{Mn}_{2} \mathrm{O}_{3}$ (JCPDS \#24-0508) were observed for the MCZ-0.80 catalyst, showing that the Mn content has exceeded the maximum that the $\mathrm{CeO}_{2}$ lattice can hold and therefore $\mathrm{Mn}_{2} \mathrm{O}_{3}$ phase is formed during calcination.

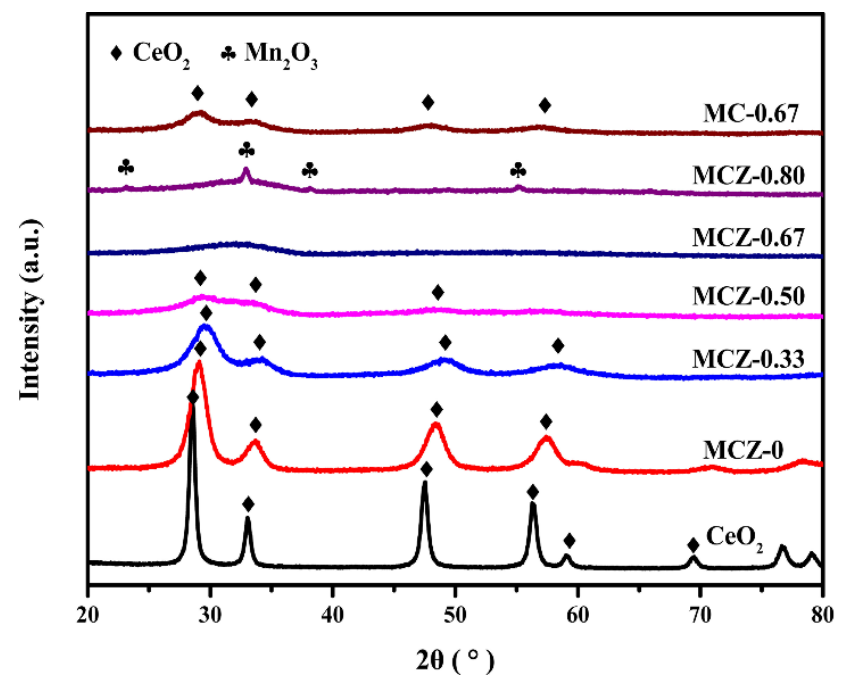

Figure 1. X-ray diffraction (XRD) patterns of MCZ-x $(x=0,0.33,0.50,0.67,0.80)$ and MC-0.67 catalysts.

Table 1. XRD, $\mathrm{N}_{2}$ adsorption-desorption and $\mathrm{H}_{2}$-temperature programmed reduction $\left(\mathrm{H}_{2}-\mathrm{TPR}\right)$ characterization data.

\begin{tabular}{|c|c|c|c|c|c|c|}
\hline Catalyst & $\begin{array}{c}\text { Lattice } \\
\text { Parameter }(\AA)^{1}\end{array}$ & $\begin{array}{l}\text { Crystallite } \\
\text { Size }(\mathrm{nm})^{2}\end{array}$ & $\begin{array}{l}\text { Brunauer-Emmett-Teller } \\
\text { Surface Area }\left(\mathrm{m}^{2} \mathrm{~g}^{-1}\right)\end{array}$ & $\begin{array}{c}\text { Pore } \\
\text { Volume } \\
\left(\mathrm{cm}^{3} \mathrm{~g}^{-1}\right)\end{array}$ & $\begin{array}{l}\text { Average } \\
\text { Pore Size } \\
\text { (nm) }\end{array}$ & $\begin{array}{c}\mathrm{H}_{2} \\
\text { Consumption } \\
\left(\mathrm{mmol} \mathrm{g}^{-1}\right)\end{array}$ \\
\hline MCZ-0 & 5.32 & 6.5 & 35.7 & 0.06 & 5.8 & 0.834 \\
\hline MCZ-0.33 & 5.29 & 3.7 & 47.0 & 0.09 & 6.4 & 2.242 \\
\hline MCZ-0.50 & 5.35 & 2.2 & 116.9 & 0.11 & 3.2 & 3.431 \\
\hline MCZ-0.67 & - & - & 135.6 & 0.19 & 4.0 & 5.081 \\
\hline MCZ-0.80 & - & - & 101.1 & 0.16 & 4.8 & 6.151 \\
\hline MC-0.67 & 5.36 & 3.5 & 67.6 & 0.12 & 5.7 & 4.334 \\
\hline
\end{tabular}

${ }^{1}$ Calculated from the $\mathrm{CeO}_{2}$ crystalline phase; ${ }^{2}$ The value estimated by Scherrer equation from the (111) reflection of $\mathrm{CeO}_{2}$. 
As is known, a lower intensity diffraction peak indicates a reduction in crystallinity and reveals the generation of more lattice defects and smaller crystallite sizes [29,34]. Thus, from Figure 1, it can be inferred that the $\mathrm{CeO}_{2}$ lattice is constantly distorted with increasing Mn doping, resulting in a decrease in crystallite size (Table 1). Similarly, the specific surface area and pore volume increase, reaching a maximum when $x=0.67$. This observation may be attributed to the production of smaller nanoparticles with an amorphous phase. Further, the addition of $\mathrm{Zr}$ promotes the transformation of the MC- 0.67 catalyst from a solid solution to an amorphous material and leads to a doubling of the specific surface area. This significant increase may be related to the larger solubility of $\mathrm{Zr}$ (maximum of $75 \mathrm{at} \%$ ) in the $\mathrm{CeO}_{2}$ lattice than that of $\mathrm{Mn}$ (maximum of 20 at\%) [35], as improved solubility can lead to the formation of more lattice defects, which is beneficial for the increase of specific surface area.
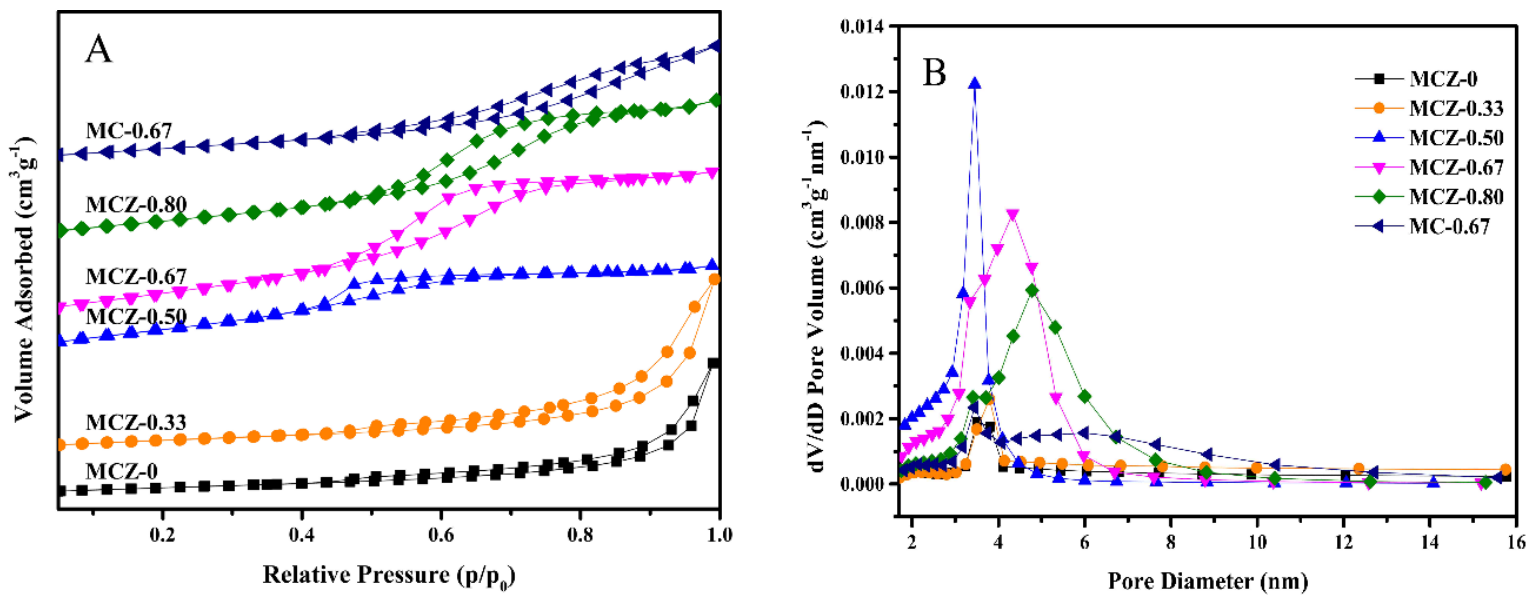

Figure 2. $\mathrm{N}_{2}$ adsorption-desorption isotherms (A) and pore size distributions (B) of MCZ-x ( $\mathrm{x}=0,0.33$, $0.50,0.67,0.80)$ and MC- 0.67 catalysts.

With regards to $\mathrm{N}_{2}$ adsorption-desorption and pore size distribution, all catalysts prepared by the sol-gel method showed a typical irreversible type IV isotherm (Figure 2A), with the MCZ-0 and MCZ-0.33 catalysts displaying a hysteresis loop of type $\mathrm{H} 3$ and the remaining four catalysts displaying a hysteresis loop of type H2. Furthermore, the sizes of the formed pores were within the range of 2 to $10 \mathrm{~nm}$ (Figure 2B and Table 1), suggesting the presence of a mesoporous structure.

\section{2. $\mathrm{H}_{2}$-Temperature Programmed Reduction $\left(\mathrm{H}_{2}\right.$-TPR) Characterization}

The influence of Mn doping on the redox properties of the catalysts was studied using $\mathrm{H}_{2}$-TPR (Figure 3). For the MCZ-0 catalyst, just one reduction peak appeared at $555^{\circ} \mathrm{C}$, ascribed to the reduction of $\mathrm{Ce}^{4+}$ on the catalyst surface [20] due to the difficulty of $\mathrm{Zr}^{4+}$ reduction at temperatures below $900{ }^{\circ} \mathrm{C}$ under this test condition [19]. After Mn doping, two overlapped reduction peaks at $351{ }^{\circ} \mathrm{C}$ and $478{ }^{\circ} \mathrm{C}$ were observed from the MCZ-0.33 catalyst, ascribed to the two-step reduction of $\mathrm{MnO}_{2} / \mathrm{Mn}_{2} \mathrm{O}_{3}$ leading to the sequential formation of $\mathrm{Mn}_{3} \mathrm{O}_{4}$ and $\mathrm{MnO}$ [36]. Similarly, with the increase of Mn content, the reduction peaks of Mn oxides moved towards lower temperatures, with the lowest reduction temperature of $321^{\circ} \mathrm{C}$ being observed for the MCZ-0.67 catalyst. This was attributed to the generation of more lattice defects following Mn doping, which is conducive to the mobility of oxygen species and thus makes the catalyst more prone to reduction.

Additionally, the introduction of Mn significantly increased the total $\mathrm{H}_{2}$ consumption, from $0.834 \mathrm{mmol} \mathrm{g}^{-1}$ for the MCZ-0 catalyst to $6.151 \mathrm{mmol} \mathrm{g}^{-1}$ for the MCZ-0.80 catalyst (Table 1 ), indicating that $\mathrm{Mn}$ oxides play a crucial role in the reducibility of MCZ-x catalysts. Nevertheless, despite an equal Mn content, the total $\mathrm{H}_{2}$ consumption of MC- 0.67 catalyst $\left(4.334 \mathrm{mmol} \mathrm{g}^{-1}\right)$ was smaller than that of MCZ-0.67 catalyst ( $5.081 \mathrm{mmol} \mathrm{g}^{-1}$ ), suggesting that the introduction of $\mathrm{Zr}$ contributes to the generation of more reactive oxygen. It is generally acknowledged that a lower reduction temperature shows better redox properties and that greater $\mathrm{H}_{2}$ consumption improves the catalytic oxidation 
activity. Therefore, it can be predicted that MCZ-x catalysts with a high Mn content should have a good catalytic performance in CB elimination.

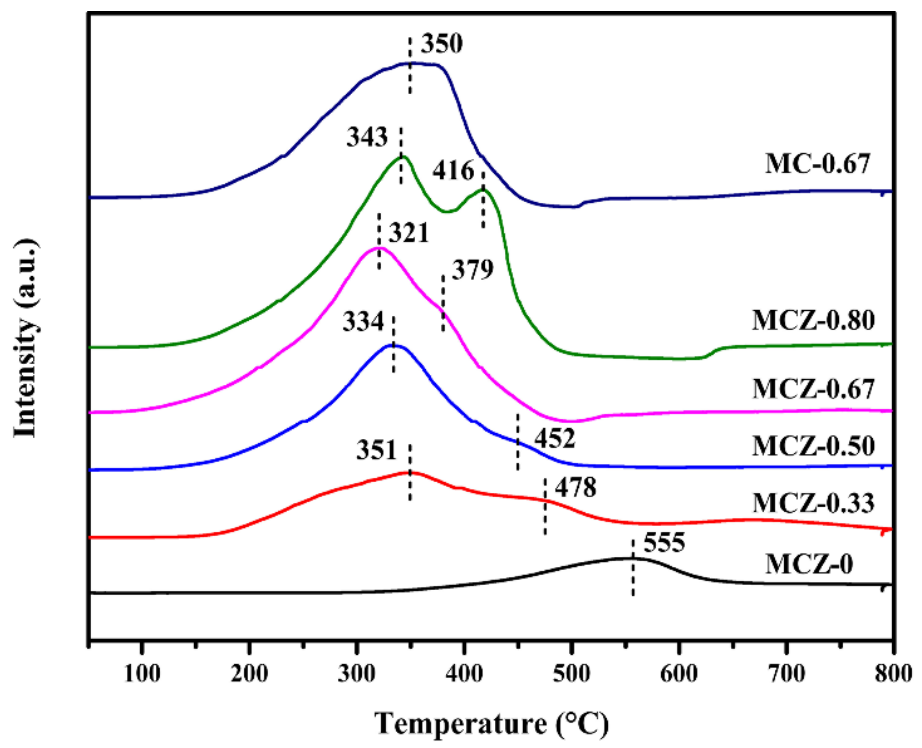

Figure 3. $\mathrm{H}_{2}$-TPR profiles of MCZ-x $(\mathrm{x}=0,0.33,0.50,0.67,0.80)$ and MC-0.67 catalysts.

\subsection{X-ray Photoelectron Spectroscopy (XPS) Characterization}

The surface characteristics of the synthesized catalysts were analyzed using XPS measurements (Figure 4 and Table 2). The Ce 3d XPS spectra were fitted and deconvolved into 10 peaks (Figure 4A), wherein those labeled as $\mathrm{v}, \mathrm{v}^{\prime \prime}, \mathrm{v}^{\prime \prime \prime}, \mathrm{u}, \mathrm{u}^{\prime \prime}$ and $\mathrm{u}^{\prime \prime \prime}$ were ascribed to $\mathrm{Ce}^{4+}$ and those labeled as $\mathrm{v}^{\prime}, \mathrm{v}_{0}, \mathrm{u}^{\prime}$ and $\mathrm{u}_{0}$ were ascribed to $\mathrm{Ce}^{3+}$ [37]. These peaks provided evidence of the coexistence of $\mathrm{Ce}^{4+}$ and $\mathrm{Ce}^{3+}$ on the catalysts surface. With the increase of Mn content, the percentage of $\mathrm{Ce}^{3+} /\left(\mathrm{Ce}^{3+}+\mathrm{Ce}^{4+}\right)$ increased firstly and then decreased, reaching a maximum value of $34.3 \%$ for the MCZ-0.67 catalyst. In contrast, the $\mathrm{Ce}^{3+}$ concentration on the MC- 0.67 catalyst surface was $31.3 \%$; therefore, the introduction of $\mathrm{Zr}$ promoted the transformation of $\mathrm{Ce}^{4+}$ to $\mathrm{Ce}^{3+}$. As previously reported, the presence of $\mathrm{Ce}^{3+}$ ions indicates the generation of oxygen vacancy and creates a charge imbalance [38]; therefore, for maintaining electrical neutrality within the catalyst, more active oxygen species (i.e., $\mathrm{O}^{2-}, \mathrm{O}_{2}{ }^{2-}, \mathrm{O}^{-}$) will be generated on the catalyst surface. Thus, it can be inferred that a catalyst with a higher percentage of $\mathrm{Ce}^{3+} /\left(\mathrm{Ce}^{3+}+\mathrm{Ce}^{4+}\right)$ could promote the rapid elimination of $\mathrm{CB}$ effectively because of the greater number of active oxygen species.

The measured Mn 2p XPS spectra showed four peaks fitted from the spin-orbit doublet of Mn $2 p_{3 / 2}$ and Mn 2p $p_{1 / 2}$ at approximately $641,653 \mathrm{eV}$ and $643,654 \mathrm{eV}$ (Figure $4 \mathrm{~B}$ ), ascribed to $\mathrm{Mn}^{3+}$ and $\mathrm{Mn}^{4+}$ species on catalyst surface, respectively [39]. The actual molar ratio of $\mathrm{Mn} /(\mathrm{Mn}+\mathrm{Ce}+\mathrm{Zr})$ measured by XPS was close to the theoretical value (Table 2), indicating that Mn oxides are uniformly distributed on the surface and bulk of the prepared catalysts. It is noteworthy that the increase of $\mathrm{Mn}$ content is accompanied by the simultaneous increase in $\mathrm{Mn}^{4+} /\left(\mathrm{Mn}^{3+}+\mathrm{Mn}^{4+}\right)$ and $\mathrm{Ce}^{3+} /\left(\mathrm{Ce}^{3+}+\mathrm{Ce}^{4+}\right)$ percentages, except for MCZ-0.80 catalyst, indicating that the doping of Mn could promote the electron transfer from $\mathrm{Mn}^{3+}$ to $\mathrm{Ce}^{4+}$ on the catalyst surface. As previously reported, more $\mathrm{Mn}^{4+}$ ions could offer more sufficient active sites during the $\mathrm{CB}$ oxidation, since the oxidation reaction usually takes place through the redox cycles between high and low valence cations [40]. For the MCZ-0.80 catalyst, the lower percentage of $\mathrm{Mn}^{4+} /\left(\mathrm{Mn}^{3+}+\mathrm{Mn}^{4+}\right)$ may be attributed to the formation of more $\mathrm{Mn}_{2} \mathrm{O}_{3}$ phase during the calcination process, as evidenced by XRD characterization. 

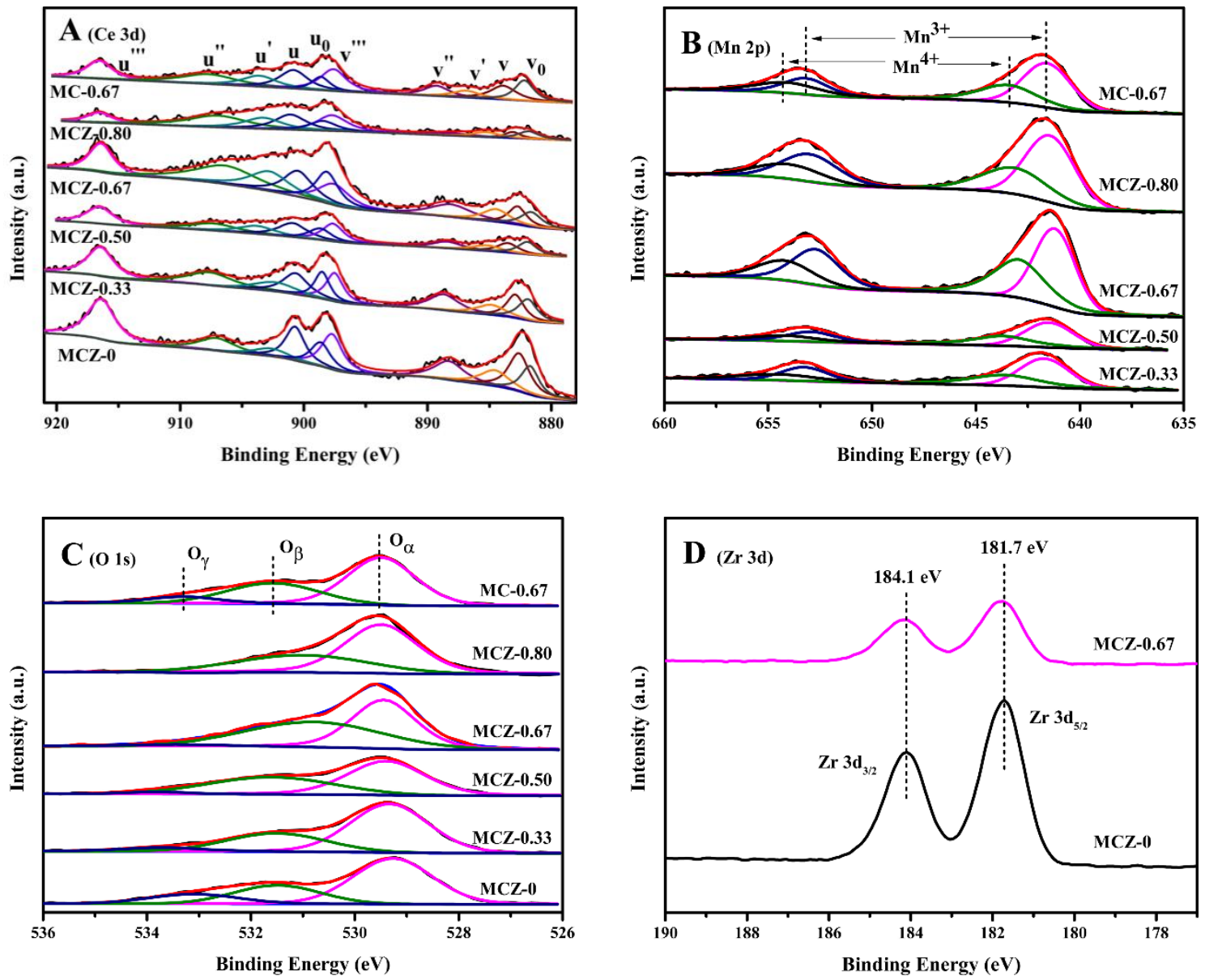

Figure 4. X-ray photoelectron spectroscopy (XPS) spectra of Ce 3d (A); Mn 2p (B); O 1s (C) and Zr 3d (D) of MCZ-x $(x=0,0.33,0.50,0.67,0.80)$ and MC-0.67 catalysts.

Table 2. XPS results of MCZ-x $(x=0,0.33,0.50,0.67,0.80)$ and MC-0.67 catalysts.

\begin{tabular}{ccccc}
\hline Catalyst & $\mathbf{M n} /(\mathbf{M n}+\mathbf{C e}+\mathbf{Z r})$ Molar Ratio & $\mathrm{Ce}^{3+} /\left(\mathrm{Ce}^{3+}+\mathrm{Ce}^{\mathbf{4 +}}\right)(\%)$ & $\mathbf{M n}^{4+} /\left(\mathbf{M n}^{3+}+\mathbf{M n}^{4+}\right)(\%)$ & $\mathbf{O}_{\beta} /\left(\mathbf{O}_{\alpha}+\mathbf{O}_{\beta}+\mathbf{O}_{\gamma}\right)(\%)$ \\
\hline MCZ-0 & 0 & 28.6 & - & 25.5 \\
MCZ- 0.33 & 0.41 & 30.5 & 40.6 & 29.3 \\
MCZ-0.50 & 0.54 & 32.5 & 41.3 & 41.3 \\
MCZ-0.67 & 0.70 & 34.3 & 42.5 & 47.7 \\
MCZ-0.80 & 0.81 & 31.8 & 37.8 & 36.0 \\
MC-0.67 & 0.72 & 31.3 & 40.7 & 31.5 \\
\hline
\end{tabular}

The O 1s XPS spectra obtained were fitted into three peaks (Figure 4C), with those at approximately $529.3-529.5 \mathrm{eV}$ being ascribed to lattice oxygen $\left(\mathrm{O}^{2-}\right.$, labeled as $\left.\mathrm{O}_{\alpha}\right)$, and those at approximately $530.8-531.6 \mathrm{eV}$ and above $533.0 \mathrm{eV}$ being ascribed to surface chemisorbed oxygen $\left(\mathrm{O}^{2-}\right.$ and $\mathrm{O}^{-}$, labeled as $\mathrm{O}_{\beta}$ ) and hydroxyl species and/or chemisorbed water species (labeled as $\mathrm{O}_{\gamma}$ ), respectively [41]. It can be observed that the percentage of $\mathrm{O}_{\beta} /\left(\mathrm{O}_{\alpha}+\mathrm{O}_{\beta}+\mathrm{O}_{\gamma}\right)$ experiences a similar variation tendency to that of $\mathrm{Ce}^{3+}$ concentration as a result of Mn doping (Table 2), confirming the analysis of surface active oxygen species in Ce $3 \mathrm{~d}$ XPS characterization. As is known, surface chemisorbed oxygen is vital for most catalytic oxidation reactions [33,42]. Therefore, compared with the other studied catalysts herein, the high $\mathrm{O}_{\beta}$ concentration on the MCZ-0.67 catalyst surface could be responsible for the enhancement in catalytic performance for $\mathrm{CB}$ elimination. Likewise, the introduction of $\mathrm{Zr}$ could likely promote the generation of more chemisorbed oxygen on the MCZ-0.67 catalyst surface compared to that on the MC-0.67 catalyst surface (Table 2), in agreement with TPR characterization. 
The Zr 3d XPS spectra of MCZ-0 and MCZ-0.67 catalysts exhibited two peaks at $181.7 \mathrm{eV}$ and $184.1 \mathrm{eV}$ (Figure 4D), ascribed to $\mathrm{Zr} 3 \mathrm{~d}_{5 / 2}$ and $\mathrm{Zr} \mathrm{3d_{3/2 }}$, respectively [43], confirming the solo presence of $\mathrm{Zr}^{4+}$ ions in the prepared catalysts [42]. As can be observed, for MCZ-0 and MCZ-0.67 catalysts, the binding energy position of $\mathrm{Zr}$ is highly similar, indicating that the chemical state of $\mathrm{Zr}$ is stable and hardly affected by the introduction of Mn.

\section{4. $\mathrm{O}_{2}$-Temperature Programmed Desorption $\left(\mathrm{O}_{2}\right.$-TPD) Characterization}

The distribution of oxygen species was also explored by $\mathrm{O}_{2}$-TPD for the MCZ-0, MCZ-0.67 and MC-0.67 catalysts (Figure 5). The desorption peak below $200{ }^{\circ} \mathrm{C}$ was attributed to physically adsorbed oxygen molecule $\left(\mathrm{O}_{2}\right)$, while the desorption peaks within $200-500{ }^{\circ} \mathrm{C}$ were ascribed to chemisorbed oxygen species $\left(\mathrm{O}^{2-}\right.$ and $\mathrm{O}^{-}$, where $\mathrm{O}^{2-}$ is easier to desorb than $\left.\mathrm{O}^{-}\right)$. The desorption peak observed above $500{ }^{\circ} \mathrm{C}$ was attributed to surface lattice oxygen $\left(\mathrm{O}^{2-}\right)$ [41].

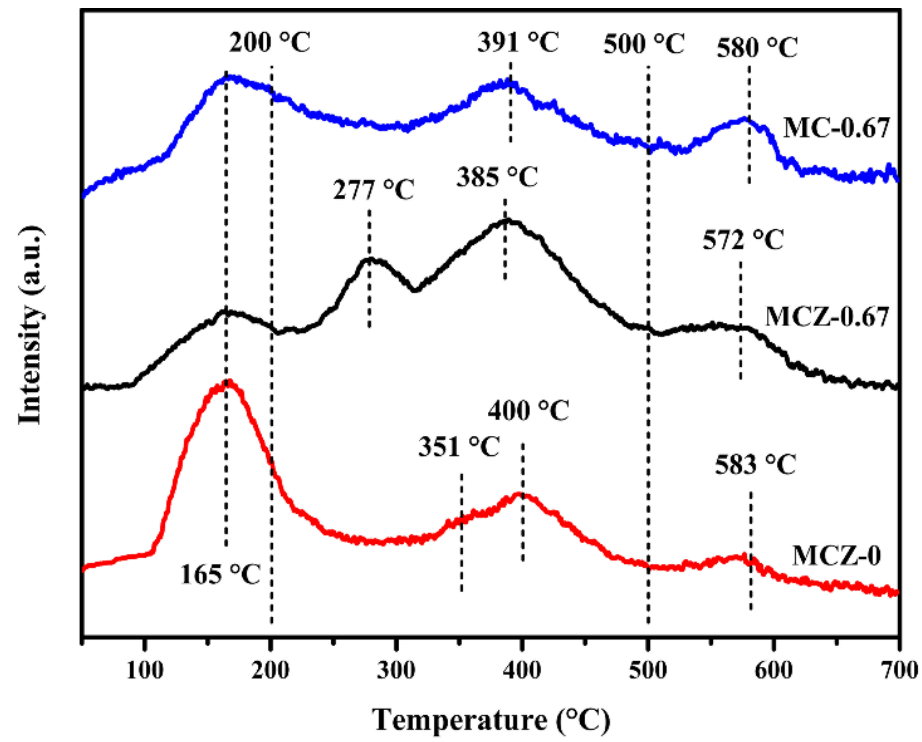

Figure 5. $\mathrm{O}_{2}$-temperature programmed desorption $\left(\mathrm{O}_{2}-\mathrm{TPD}\right)$ patterns of MCZ-0, MCZ-0.67 and MC-0.67 catalysts.

For the MCZ-0 catalyst specifically, four peaks were observed at $165{ }^{\circ} \mathrm{C}, 351{ }^{\circ} \mathrm{C}, 400{ }^{\circ} \mathrm{C}$ and $583{ }^{\circ} \mathrm{C}$, corresponding to the desorption of $\mathrm{O}_{2}, \mathrm{O}_{2}{ }^{-}, \mathrm{O}^{-}$and $\mathrm{O}^{2-}$, respectively. The MCZ-0.67 catalyst presented similar desorption peaks, yet with a much greater peak intensity of chemisorbed oxygen species, indicating that the addition of Mn contributes to the adsorption of active oxygen species on the catalyst surface. This is in good agreement with the $\mathrm{O}$ 1s XPS characterization, and likely also correlated to the large BET and mesoporous structure of the MCZ-0.67 catalyst, which are conducive to the adsorption and activation of gas-phase oxygen on the catalyst surface. The desorption peaks of the MCZ-0.67 catalyst showed a shift towards lower temperatures as compared with the MCZ-0 catalyst. As is known, a larger peak intensity and lower desorption temperature correspond to improved catalytic activity [44], which perhaps forecast the better catalytic performance of the MCZ-0.67 catalyst for CB elimination. Finally, the MC-0.67 catalyst exhibited three distinct desorption peaks; it is likely that the $\mathrm{O}_{2}{ }^{-}$desorption peak may have been covered by adjacent peaks. As compared with the MCZ-0.67 catalyst, it is obvious that the addition of $\mathrm{Zr}$ contributes to the improvement of catalytic performance by providing more active oxygen species. 

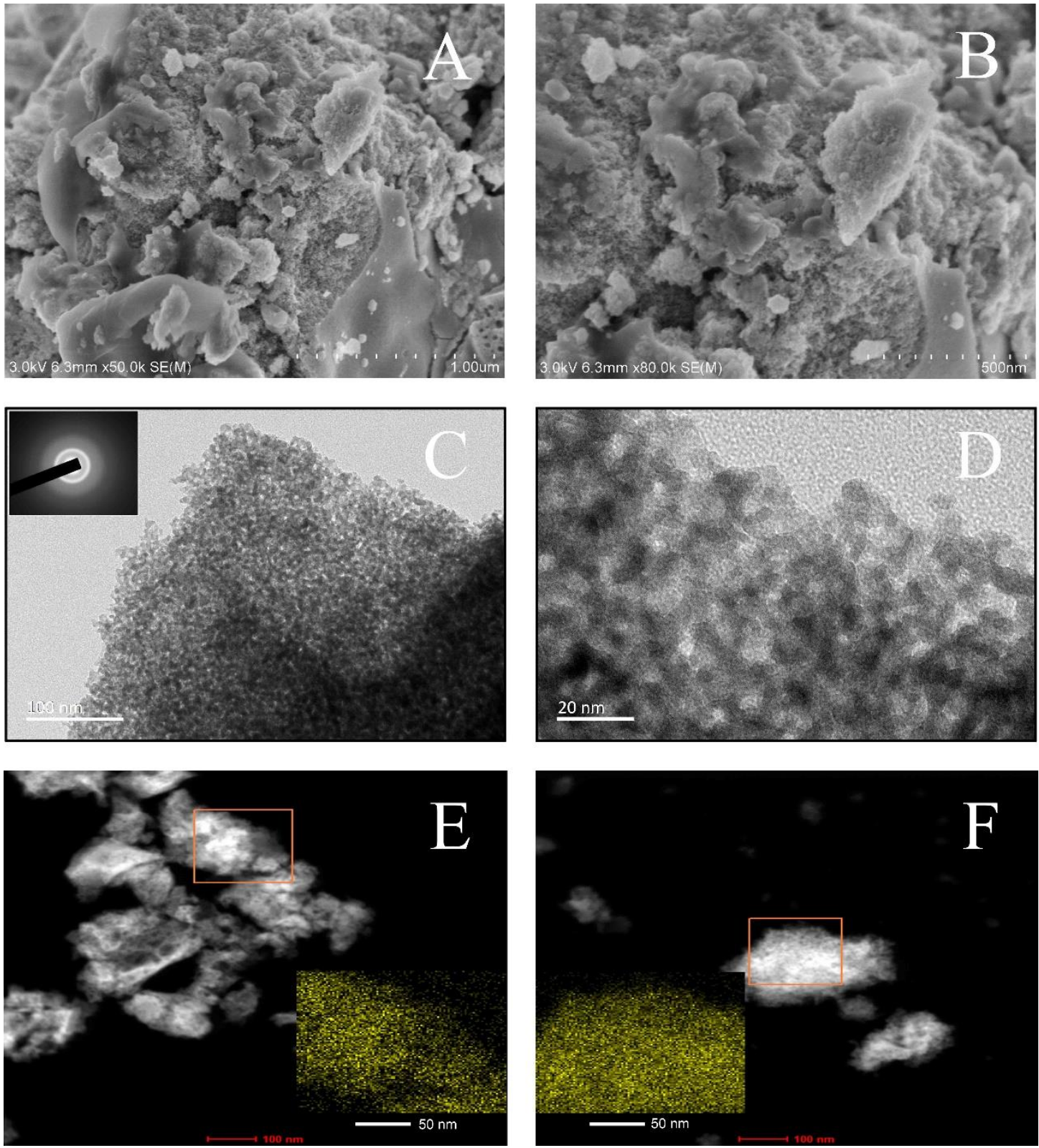

Figure 6. Scanning electron microscope (SEM) (A,B) and transmission electron microscope (TEM) (C,D) images of MCZ-0.67 catalyst, the inset is the pattern of the selected area electron diffraction (SAED). Scanning transmission electron microscope (STEM) images of MCZ-0.33 (E) and MCZ-0.67 (F) catalysts, the insets are Mn-element mappings.

The correlation between the catalytic performance and morphological characteristics of the promising MCZ-0.67 catalyst was studied using SEM and TEM. Figure 6A,B showed that the MCZ-0.67 catalyst presented sponge-like surface with a large degree of porosity, in agreement with its large BET. Closer observation using TEM (Figure 6C,D) showed that this catalyst was composed of well-distributed nanoparticles with a size of $6-10 \mathrm{~nm}$, and their accumulation led to the formation of mesopores with a size of 3-9 nm. This morphology could contribute to the good catalytic performance to some extent by providing a large quantity of adsorption sites [45]. It is reported that nanoparticles showed promising applications for catalytic reactions due to their high surface-to-volume ratio [46]. The selected area electron diffraction (SAED) pattern exhibited in the inset further confirmed that the prepared MCZ-0.67 
catalyst is amorphous since no typical diffraction rings or spot patterns were observed [47], in agreement with the results of the XRD characterization. The bright squares in Figure $6 \mathrm{E}, \mathrm{F}$ indicated that the concentration and distribution of Mn species in MCZ-0.67 catalyst were better than those in MCZ-0.33 catalyst. As reported, the content and distribution of active Mn species can greatly influence the performance of the catalyst [48].

\subsection{Catalytic Activity for Chlorobenzene (CB) Combustion}

The catalytic activity of the prepared catalysts during CB combustion was assessed (Figure 7 and Table 3). The MCZ-0 catalyst exhibited the lowest catalytic activity, with deactivation occurring after $250{ }^{\circ} \mathrm{C}$. Following Mn doping, the catalytic activity and anti-poisoning ability were significantly improved. Specifically, MCZ-0.33 (Rs $=0.598 \mu \mathrm{mol} \mathrm{m}{ }^{-2} \mathrm{~h}^{-1}$ ) exhibited an increased reaction rate compared to that of MCZ-0 (Rs $\left.=0.468 \mu \mathrm{mol} \mathrm{m} \mathrm{m}^{-2} \mathrm{~h}^{-1}\right)$ at $130{ }^{\circ} \mathrm{C}$. This increase in reaction rate continued until $\mathrm{x}=0.67\left(\mathrm{Rs}=0.716 \mu \mathrm{mol} \mathrm{m}{ }^{-2} \mathrm{~h}^{-1}\right)$, after which a reversal was observed. Thus, the most abundant active sites may be generated on the MCZ-0.67 catalyst surface, as evidenced from Figure 6 that more active Mn species were evenly distributed in the catalyst. Therefore, the optimal Mn content for CB elimination was defined at 0.67 .

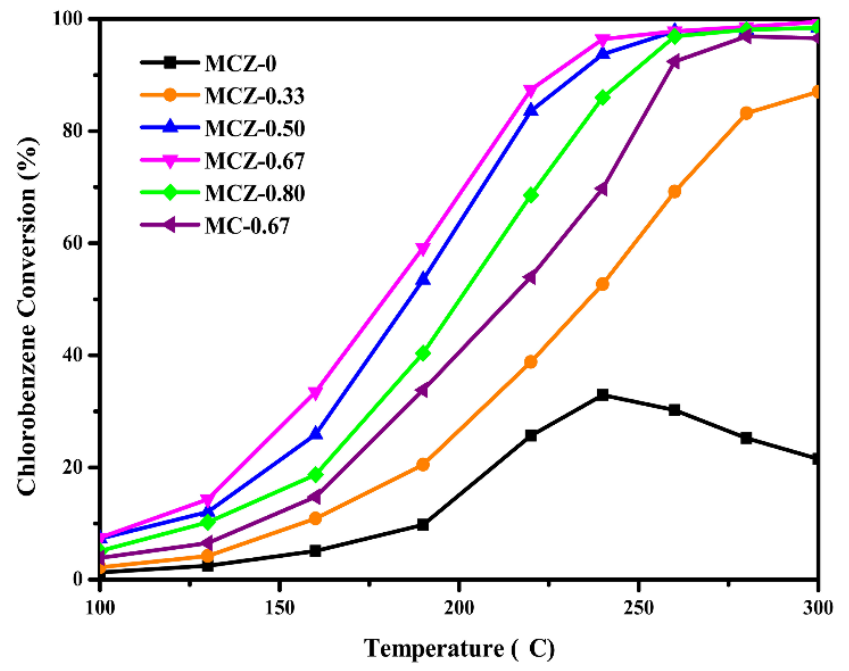

Figure 7. The catalytic activity of MCZ-x $(x=0,0.33,0.50,0.67,0.80)$ and MC- 0.67 catalysts for chlorobenzene (CB) combustion; gas composition: $1000 \mathrm{ppm} \mathrm{CB}, 21 \% \mathrm{O}_{2}$; gas hourly space velocity $(\mathrm{GHSV})=20,000 \mathrm{~h}^{-1}$.

Table 3. Results of activity tests on CB combustion over the prepared catalysts.

\begin{tabular}{|c|c|c|c|}
\hline Catalyst & $\mathrm{T}_{90}\left({ }^{\circ} \mathrm{C}\right)^{1}$ & $\mathrm{~S}_{\mathrm{CO} 2}(\%)^{2}$ & Rs at $130{ }^{\circ} \mathrm{C}\left(\mu \mathrm{mol} \mathrm{m} \mathrm{m}^{-2} \mathrm{~h}^{-1}\right)^{3}$ \\
\hline MCZ-0 & $>300$ & 86.3 & 0.468 \\
\hline MCZ-0.33 & $>300$ & 98.4 & 0.598 \\
\hline MCZ-0.50 & 233 & 98.9 & 0.693 \\
\hline MCZ-0.67 & 226 & 99.2 & 0.716 \\
\hline MCZ-0.80 & 248 & 99.0 & 0.675 \\
\hline MC-0.67 & 258 & 97.7 & 0.644 \\
\hline
\end{tabular}

1 The temperature at which $\mathrm{CB}$ conversion reaches $90 \% .{ }^{2} \mathrm{CO}_{2}$ selectivity measured at $300{ }^{\circ} \mathrm{C}$ and calculated based on formula: $\mathrm{S}_{\mathrm{CO} 2}=\left[\mathrm{CO}_{2}\right] /\left(\left[\mathrm{CO}_{2}\right]+[\mathrm{CO}]\right) \cdot{ }^{3}$ Reaction rate of $\mathrm{CB}$ oxidation normalized by catalyst specific surface area.

The MCZ-0.67 catalyst achieved $90 \%$ CB conversion at approximately $226^{\circ} \mathrm{C}$ (Table 3 ), which is lower than most transition metal oxide catalysts reported in previous literature (Table 4). Furthermore, this temperature was approximately $32{ }^{\circ} \mathrm{C}$ lower compared with the $\mathrm{T}_{90}$ of the MC-0.67 catalyst, likely due to the changes in physicochemical properties of the MC-0.67 catalyst following $\mathrm{Zr}$ doping, 
including the increase in BET surface area and active oxygen species. Additionally, the measurement of $\mathrm{CO}_{2}$ and $\mathrm{CO}$ concentrations in the off-gas (Table 3) showed that the prepared MCZ-x catalysts, except for the MCZ-0 catalyst, presented a greater than $98 \% \mathrm{CO}_{2}$ selectivity, indicating that these catalysts possess a good deep catalytic oxidation of CB.

Table 4. Main data of literature reports on CB elimination over transition metal oxide catalysts.

\begin{tabular}{ccccc}
\hline Catalyst & Concentration $(\mathbf{p p m})$ & GHSV $\left(\mathbf{h}^{-\mathbf{1}}\right)$ & $\mathbf{T}_{\mathbf{9 0}}\left({ }^{\circ} \mathbf{C}\right)$ & Refs. \\
\hline $4 \mathrm{Ce} 1 \mathrm{Cr}$ & 1000 & 15,000 & 260 & {$[7]$} \\
$\mathrm{MnO}_{\mathbf{x}}(0.86)-\mathrm{CeO}{ }_{2}$ & 1000 & 15,000 & $\sim 240$ & {$[11]$} \\
$10 \% \mathrm{Sn}-\mathrm{Mn}-\mathrm{Ti}$ & 500 & 20,000 & 177 & {$[32]$} \\
$\mathrm{Mn}(0.86)-\mathrm{CeLa}$ & 1000 & 15,000 & 279 & {$[49]$} \\
$\mathrm{CuMnCeO}$ & 600 & 30,000 & 255 & {$[50]$} \\
$\mathrm{La}_{0.8} \mathrm{Sr}_{0.2} \mathrm{MnO}_{3}$ & 1000 & 15,000 & 291 & {$[51]$} \\
$2.1 \% \mathrm{VO}_{\mathbf{x}} / \mathrm{CeO}_{2}$ & 1000 & 30,000 & $\sim 308$ & {$[52]$} \\
$\mathrm{Mn}_{8} \mathrm{Co}_{1} \mathrm{Ce}_{1} / \mathrm{cordierite}$ & 500 & 15,000 & 325 & {$[12]$} \\
$\mathrm{Mn}-\mathrm{Ce}-\mathrm{Mg} / \mathrm{Al}_{2} \mathrm{O}_{3}$ & 1000 & 15,000 & 315 & {$[53]$} \\
$\mathrm{MCZ}-0.67$ & 1000 & 20,000 & 226 & This work \\
\hline
\end{tabular}

\subsection{Catalyst Stability}

Stability is another important consideration in the evaluation of catalytic performance, especially for the removal of CVOCs. Generally, dissociated chlorine species can occupy the catalyst active sites through adsorption or metal chloride formation, resulting in a decline in activity and stability, commonly known as chlorine poisoning [1]. Additionally, due to the strong electronegativity, chlorine deposited on the catalyst surface will lead to an electron shift towards the chlorine species [29], inhibiting the generation of active oxygen species. Accordingly, the timely removal of chlorine species from the catalyst surface is crucial for maintaining a stable catalytic activity.

The variation in catalytic activity over time at $300{ }^{\circ} \mathrm{C}$ for $30 \mathrm{~h}$ was assessed herein (Figure 8). The activity of the prepared catalysts decreased to varying degrees within the initial $2.5 \mathrm{~h}$ likely due to the rapid deposition of chlorine species on the active sites. The activity of the MCZ-0 catalyst was largely exhausted at the end of the stability test, mainly due to its poor redox properties (revealed in TPR characterization). With the introduction of $\mathrm{Mn}$, the increased BET surface area and surface active oxygen could significantly improve the catalyst chlorine resistance by providing more active sites and accelerating the removal of deposited chlorine. It is worth noting that the MCZ-0.67 catalyst maintained a high and stable catalytic activity $(>95 \%)$ and showed the best resistance to chlorine poisoning throughout the stability test. In contrast, the MC- 0.67 catalyst showed a significant decrease in catalytic activity, from $96 \%$ to $52 \%$, after $30 \mathrm{~h}$ of continuous reaction. Therefore, the addition of $\mathrm{Zr}$ led to an improvement in catalytic stability.

Chlorine resistance was assessed according to the $\mathrm{Cl} 2 \mathrm{p}$ XPS spectra of the used MCZ-0, MCZ-0.67 and MC- 0.67 catalysts after the stability tests (Figure 9). The two overlapping peaks appearing at approximately $198.1 \mathrm{eV}$ and $199.6 \mathrm{eV}$ were attributed to the $\mathrm{Cl} 2 \mathrm{p}_{3 / 2}$ and $\mathrm{Cl} 2 \mathrm{p}_{1 / 2}$ core levels, respectively [54]. Their presence confirmed the occurrence of chlorine deposition on the catalyst surface. Specifically, according to the estimation from the peak area of $\mathrm{Cl} 2 \mathrm{p}_{3 / 2}$, the surface chlorine content of the used MCZ-0, MCZ-0.67 and MC-0.67 catalysts was 5.9 at $\%, 4.0$ at $\%$ and 5.2 at $\%$, respectively. Obviously, the MCZ-0.67 catalyst had the best chlorine resistance, with $\mathrm{Zr}$ addition effectively inhibiting chlorine poisoning. 


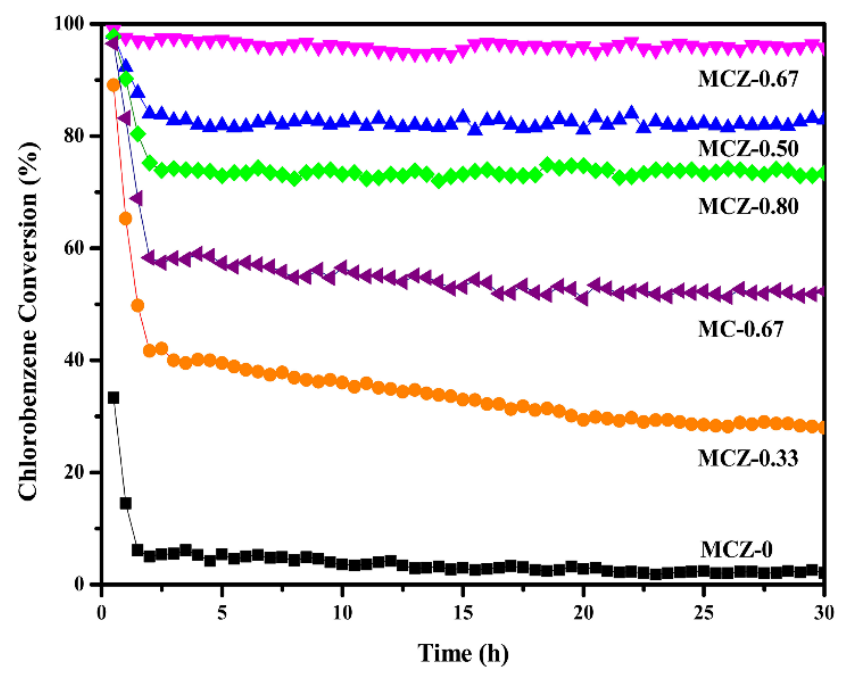

Figure 8. Stability tests of MCZ-x ( $x=0,0.33,0.50,0.67,0.80)$ and MC-0.67 catalysts for CB elimination during $30 \mathrm{~h}$ of continuous reaction at $300^{\circ} \mathrm{C}$, gas composition: $1000 \mathrm{ppm} \mathrm{CB}, 21 \% \mathrm{O}_{2}$; GHSV $=20,000 \mathrm{~h}^{-1}$.

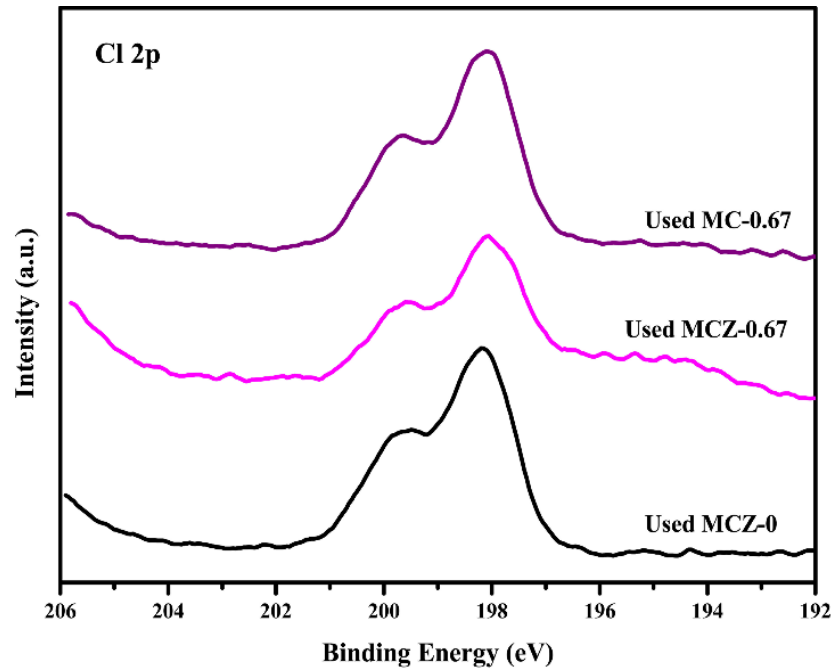

Figure 9. $\mathrm{Cl} 2 \mathrm{p}$ XPS spectra of the used MCZ-0, MCZ-0.67 and MC-0.67 catalysts.

Apart from time-based stability, the practical application process subjects catalysts to complicated and variable operating conditions. Therefore, the successive influence of $\mathrm{CB}$ concentration, space velocity and water vapor on $\mathrm{CB}$ elimination and $\mathrm{HCl}$ selectivity $\left([\mathrm{HCl}] /\left([\mathrm{HCl}]+\left[\mathrm{Cl}_{2}\right]\right)\right)$ were studied for the MCZ-0.67 catalyst at $300{ }^{\circ} \mathrm{C}$ (Figure 10). Both higher CB concentration (2500 ppm) and space velocity $\left(40,000 \mathrm{~h}^{-1}\right)$ led to a serious decrease in activity (lower than $60 \%$ ), while lower space velocity $\left(10,000 \mathrm{~h}^{-1}\right)$ resulted in an almost complete elimination of CB. The influence of CB concentration indicated that the catalytic efficiency would be overloaded when handling a large amount of reactants, and the influence of lower space velocity was attributed to a more sufficient oxidation caused by the longer residence time of reactants through the catalyst bed. Meanwhile, Deacon reaction (the generation of $\mathrm{Cl}_{2}$ ) was similarly influenced, as can be seen from the higher $\mathrm{HCl}$ selectivity at greater space velocity. Under water vapor condition ( $2.3 \mathrm{vol} \%$ ), the conversion of $\mathrm{CB}$ dropped to $72 \%$, which is attributed to the competitive adsorption of $\mathrm{CB}$ and $\mathrm{H}_{2} \mathrm{O}$ on the surface active sites [55]. In contrast, the selectivity of $\mathrm{HCl}$ was as high as $99 \%$, showing that water can effectively inhibit the generation of $\mathrm{Cl}_{2}$. According to previous report, the flowing water vapor can wash the catalyst surface and promote the formation of $\mathrm{HCl}$ by the dissociated chlorine species [56]. Thus, as shown above, despite undergoing various 
operating conditions, $\mathrm{CB}$ conversion was maintained at approximately $90 \%$, further confirming the good catalytic performance of the MCZ-0.67 catalyst.

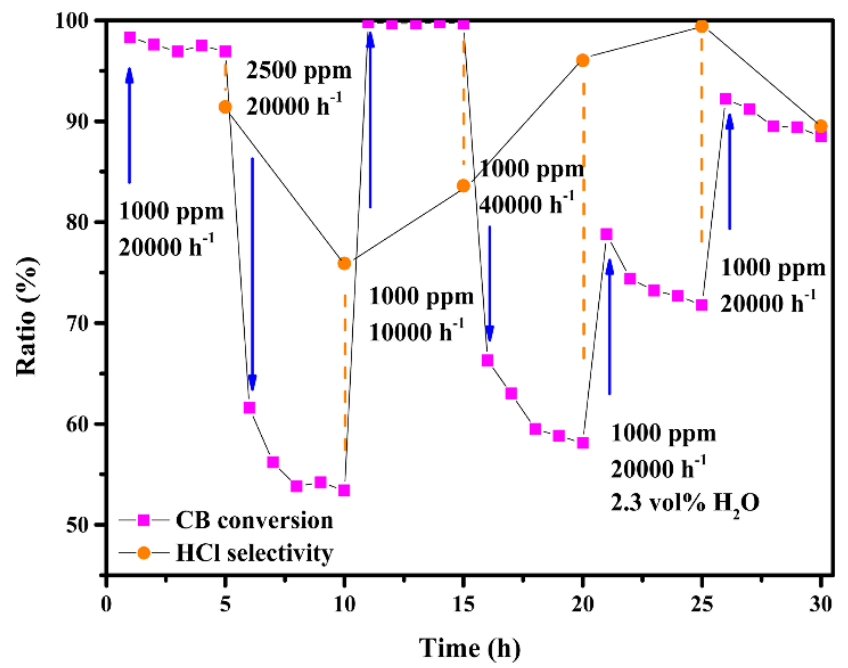

Figure 10. The successive influence of $\mathrm{CB}$ concentration, space velocity and water vapor on $\mathrm{CB}$ conversion and $\mathrm{HCl}$ selectivity over the MCZ-0.67 catalyst at $300{ }^{\circ} \mathrm{C}$.

\subsection{Regeneration of Catalyst}

Catalytic combustion is a heterogeneous catalytic oxidation process, varying from homogeneous catalysis, catalysts used in the tests can be easily separated from the reaction system [57]. Thus, it is of great significance to explore the reuse of catalysts (Figure 11). After the fourth reaction run, MCZ-0.67 catalyst suffers a decrease in catalytic efficiency from $98 \%$ (fresh catalyst) to approximately $80 \%$ at $300{ }^{\circ} \mathrm{C}$. Regeneration was carried out by calcining the above used catalyst at $350^{\circ} \mathrm{C}$ for $12 \mathrm{~h}$ in air and nitrogen atmosphere respectively. As shown in Figure 11, after treatment in air, the activity of MCZ-0.67 catalyst recovered to approximately $95 \%$, while that of the catalyst treated in nitrogen remained almost unchanged. This phenomenon indicates that the presence of oxygen contributes to the regeneration of the catalyst and the used MCZ-0.67 catalyst can be recycled by calcination in air. The re-enhancement of catalytic activity may be attributed to the reaction of oxygen species with chlorine species at high temperature, which exposes the active sites occupied by chlorine species again [11].

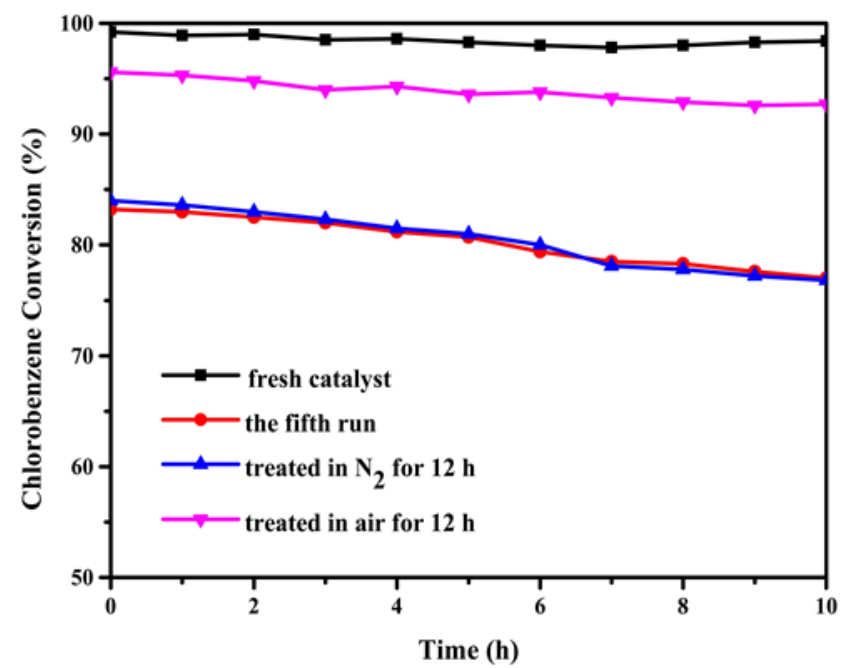

Figure 11. The catalytic efficiency of the MCZ-0.67 catalyst treated under different conditions; activity test condition: $300{ }^{\circ} \mathrm{C}$ for $10 \mathrm{~h}$; gas composition: $1000 \mathrm{ppm} \mathrm{CB}, 21 \% \mathrm{O}_{2} ; \mathrm{GHSV}=20,000 \mathrm{~h}^{-1}$. 
During the above $10 \mathrm{~h}$ of continuous test, all the off-gas was bubbled through a $5 \% \mathrm{HNO}_{3}$ solution. After concentration, inductively coupled plasma-atomic emission spectroscopy (ICP-AES, Thermo Scientific 6300) was used to measure the metal elements in the solution. Results showed that the corresponding $\mathrm{Mn}, \mathrm{Ce}$ and $\mathrm{Zr}$ elements were not detected (detection limit is $0.01 \mathrm{ppm}$ ), indicating that the prepared MCZ-0.67 catalyst was stable in composition, and no metal elements were leached into the final effluents under this reaction media.

\subsection{Product Analysis}

In order to better elucidate the $\mathrm{CB}$ oxidation process, the $\mathrm{CB}$ decomposition products in the off-gas were collected and analyzed. Based on the calculation of carbon balance and chlorine balance of reactants, the carbon distribution and chlorine distribution of converted $\mathrm{CB}$ at different conversion rates (i.e., $20 \%, 50 \%, 90 \%$ and $100 \%$ CB conversion, the corresponding temperature was at approximately 145 , 185,235 and $300{ }^{\circ} \mathrm{C}$, respectively) over the MCZ-0.67 catalyst were obtained (Figure 12). The carbon in the decomposed $\mathrm{CB}$ mainly existed in the form of $\mathrm{CO}_{2}$, with $\mathrm{CO}_{2}$ selectivity increasing with the increase in catalytic activity (Figure 12A). When $\mathrm{CB}$ was completely oxidized, the selectivity of carbon to carbon oxides $\left(\mathrm{CO}_{2}\right.$ and $\left.\mathrm{CO}\right)$ exceeded $99.5 \%$, of which the $\mathrm{CO}$ content was less than $1 \%$. However, the selectivity of chlorine to $\mathrm{HCl}$ in converted $\mathrm{CB}$ was low at $20 \%$ and $50 \% \mathrm{CB}$ conversion (Figure 12B), likely related to the easier adsorption of chlorine species on the catalyst surface at lower temperatures [12]. Furthermore, $\mathrm{Cl}_{2}$ was detected at $90 \% \mathrm{CB}$ conversion, indicating the occurrence of the Deacon reaction. Indeed, it has been previously reported that the higher temperature and modified $\mathrm{Mn}$ species are both favorable for the production of $\mathrm{Cl}_{2}$ [49]. $\mathrm{Cl}$ balance gives the calculation result of $84 \%$ at $100 \%$ CB conversion, combined with the high carbon oxides selectivity at this time, the occurrence of chlorine deposition on catalyst surface can be confirmed, which may be related to the formation of metal chlorides or metal oxychlorides $\left(\mathrm{MCl}_{\mathrm{x}}\right.$ or $\left.\mathrm{MOCl}_{\mathrm{x}}\right)$.
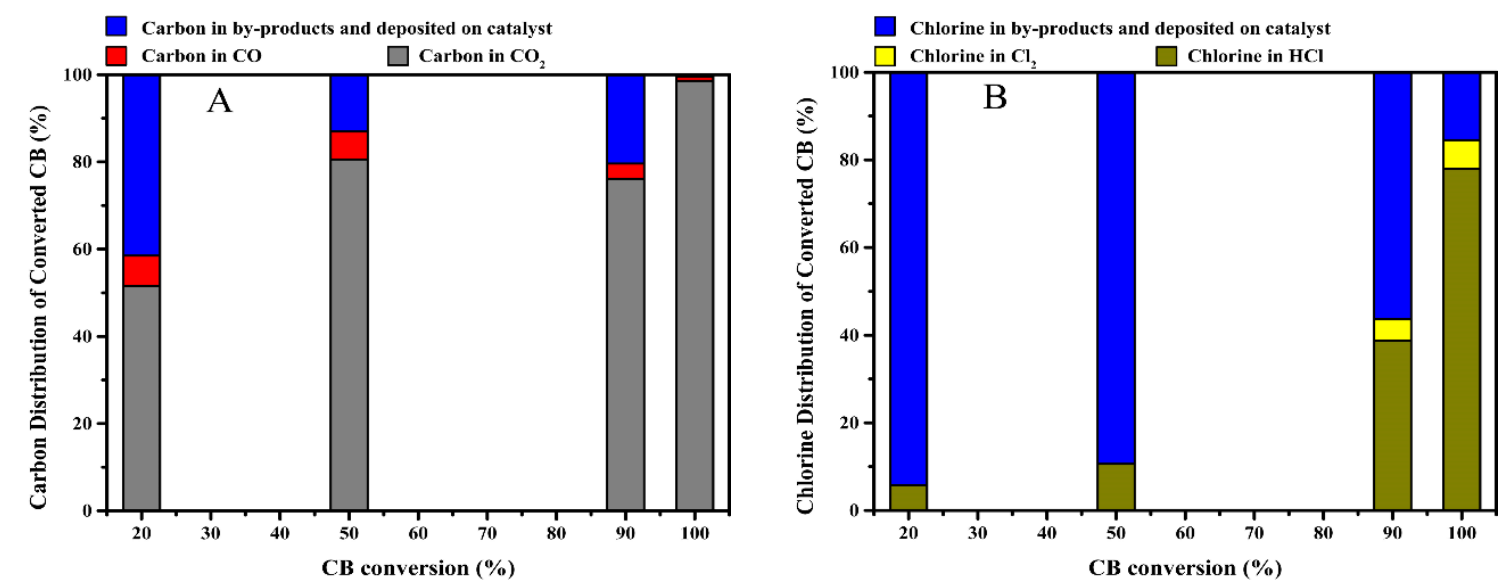

Figure 12. Carbon distribution (A) and chlorine distribution (B) of converted CB at different conversion rates over the MCZ-0.67 catalyst.

The production of polychlorinated by-products is inevitable during the oxidation of chlorinated aromatic hydrocarbons due to the strong reactivity of chlorine species. Thus, an evaluation of the $\mathrm{CB}$ decomposition products is required. Herein, the GC-MS method was employed for the detection of probable trace products (Figure 13), showing that various polychlorinated by-products were produced at $90 \% \mathrm{CB}$ conversion, including dichlorobenzene $\left(\mathrm{C}_{6} \mathrm{H}_{4} \mathrm{Cl}_{2}\right.$, ortho-6 ppm, meta-2 ppm, para-16 ppm), tetrachloroethylene $\left(\mathrm{C}_{2} \mathrm{Cl}_{4}, 15 \mathrm{ppm}\right)$, trichloroethylene $\left(\mathrm{C}_{2} \mathrm{HCl}_{3}, 7 \mathrm{ppm}\right)$, dichloromethane $\left(\mathrm{CH}_{2} \mathrm{Cl}_{2}\right.$, $3 \mathrm{ppm})$ and trace amounts of trichlorobenzene $\left(\mathrm{C}_{6} \mathrm{H}_{3} \mathrm{Cl}_{3},<1 \mathrm{ppm}\right)$ and hexachlorobutadiene $\left(\mathrm{C}_{4} \mathrm{Cl}_{6}\right.$, $<1 \mathrm{ppm}$ ). Their presence directly confirms the occurrence of chlorination reactions during $\mathrm{CB}$ oxidation and clearly depicts the break-down process of the $\mathrm{C}-\mathrm{C}$ bond from a hexatomic ring to a short chain. It has been previously reported that the formation of these polychlorinated by-products is initiated 
from the electrophilic substitution of chlorine species [55], and according to the chlorine distribution during $\mathrm{CB}$ oxidation (Figure 12B), it can be reasonably speculated that the chlorine species dissociated from the catalyst surface and the $\mathrm{Cl}_{2}$ resulting from the Deacon reaction are responsible for the substitution reaction. In addition, it is well acknowledged that the destruction of CB molecule begins with dechlorination reaction due to the lower dissociation energy of the $\mathrm{C}-\mathrm{Cl}$ bond than that of $\mathrm{C}-\mathrm{H}$ bond [49], and the resulting intermediate benzene is then further ring-opened and oxidized by active oxygen species. Herein, among the products of $\mathrm{CB}$ decomposition, benzene, the incomplete oxidation product of $\mathrm{CB}$, was not detected, while it is the only organic by-product during the oxidation of $\mathrm{CB}$ over $\mathrm{Mn}_{0.8} \mathrm{Ce}_{0.2} \mathrm{O}_{2}$ catalyst [55]. This phenomenon may be ascribed to the competitive adsorption for the same active sites between polychlorobenzene and benzene; herein, benzene seems to be preferentially oxidized over the MCZ-0.67 catalyst. This result may be correlated to the higher electron cloud density of benzene than that of polychlorobenzene, thus facilitating the formation of $\pi$-complex in the adsorption process [52]. As the reaction temperature increases, these small amounts of polychlorinated by-products can be further oxidized under the strong oxidation ability of active oxygen species, as evidenced from the observations in Figure 13, wherein the corresponding peaks are almost invisible at $100 \%$ CB conversion. Based on the above analyses, a possible reaction path of CB oxidation over the MCZ-0.67 catalyst was proposed and presented in Scheme 1.

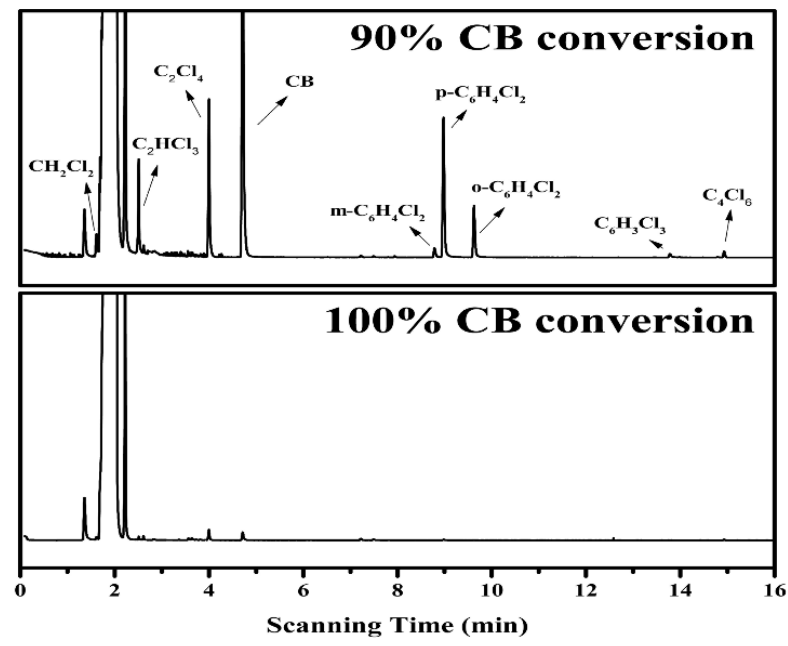

Figure 13. The gas chromatography-mass spectrometer (GC-MS) chromatograms of organic by-products in off-gas at different $\mathrm{CB}$ conversion rates over the MCZ-0.67 catalyst.

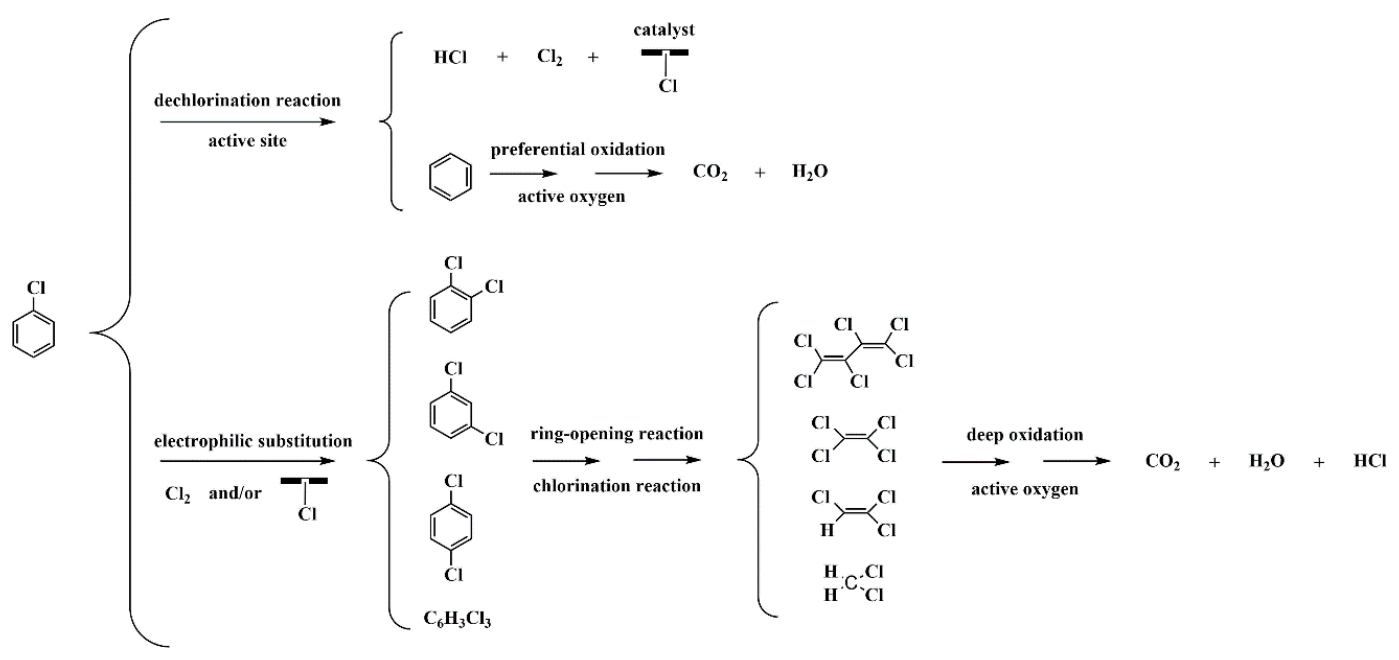

Scheme 1. Proposed reaction path of CB oxidation over the MCZ-0.67 catalyst. 


\section{Conclusions}

$\mathrm{Mn}-\mathrm{Ce}-\mathrm{Zr}-\mathrm{O}$ catalysts doped with a varying Mn concentration were prepared and assessed for the catalytic combustion of CB. Nanosized MCZ-0.67 catalyst with amorphous phase was found to exhibit superior catalytic activity and chlorine resistance among the studied catalysts, and presented excellent performance in stability tests, including time-based stability and the successive influence of the various operating conditions. At the same time, the used MCZ-0.67 catalyst can be recycled by calcination in air at $350^{\circ} \mathrm{C}$ for $12 \mathrm{~h}$. Characterization results showed that the doping of $\mathrm{Mn}$ played a dominant role in improving the catalytic performance by increasing the BET surface area, improving the redox properties and increasing the percentage of surface active oxygen. Product analysis showed that trace amounts of polychlorinated by-products did occur during CB oxidation, attributed to the chlorination reactions caused by the dissociated chlorine species and the $\mathrm{Cl}_{2}$ generated. At $300{ }^{\circ} \mathrm{C}$, these by-products can be completely oxidized and a high $\mathrm{CO}_{2}$ selectivity $(>99 \%)$ was obtained under the strong oxidation ability of the MCZ-0.67 catalyst. Therefore, the MCZ-0.67 catalyst prepared herein shows promise for applications to eliminate CVOCs. In addition, although $\mathrm{ZrO}_{2}$ is inactive, the changes in physical structure and chemical properties of catalysts resulting from $\mathrm{Zr}$ introduction are essential for maintaining their high and stable catalytic activity.

Author Contributions: Y.X. and Z.L. designed the experiments; L.Z., X.L. and L.Y. performed the experiments; P.Y. contributed to the characterization analysis; L.Z. wrote the manuscript; P.W. and X.J. revised the manuscript. All authors read and approved the manuscript.

Funding: This research was funded by the National Key Research and Development Project of China during the 13th Five-Year Plan Period (2017YFB0602500), the Natural Science Foundation of China (21373034), and the University Science Research Project of Jiangsu Province (16KJA610002).

Conflicts of Interest: The authors declare no conflict of interest.

\section{References}

1. Yang, S.; Zhao, H.; Dong, F.; Zha, F.; Tang, Z. Highly efficient catalytic combustion of o-dichlorobenzene over three-dimensional ordered mesoporous cerium manganese bimetallic oxides: A new concept of chlorine removal mechanism. Mol. Catal. 2019, 463, 119-129. [CrossRef]

2. Huang, B.; Lei, C.; Wei, C.; Zeng, G. Chlorinated volatile organic compounds (Cl-VOCs) in environment-Sources, potential human health impacts, and current remediation technologies. Environ. Int. 2014, 71, 118-138. [CrossRef] [PubMed]

3. Maghsoodi, S.; Towfighi, J.; Khodadadi, A.; Mortazavi, Y. The effects of excess manganese in nano-size lanthanum manganite perovskite on enhancement of trichloroethylene oxidation activity. Chem. Eng. J. 2013, 215-216, 827-837. [CrossRef]

4. Shokouhimehr, M.; Hong, K.; Lee, T.; Moon, C.; Hong, S.; Zhang, K.; Suh, J.; Choi, K.; Varma, R.; Jang, H. Magnetically retrievable nanocomposite adorned with Pd nanocatalysts: Efficient reduction of nitroaromatics in aqueous media. Green Chem. 2018, 20, 3809-3817. [CrossRef]

5. Cao, S.; Fei, X.; Wen, Y.; Sun, Z.; Wang, H.; Wu, Z. Bimodal mesoporous TiO2 supported Pt, Pd and Ru catalysts and their catalytic performance and deactivation mechanism for catalytic combustion of Dichloromethane $\left(\mathrm{CH}_{2} \mathrm{Cl}_{2}\right)$. Appl. Catal. A Gen. 2018, 550, 20-27. [CrossRef]

6. Huang, H.; Dai, Q.; Wang, X. Morphology effect of $\mathrm{Ru} / \mathrm{CeO}_{2}$ catalysts for the catalytic combustion of chlorobenzene. Appl. Catal. B Environ. 2014, 158-159, 96-105. [CrossRef]

7. Yang, P.; Shi, Z.; Yang, S.; Zhou, R. High catalytic performances of $\mathrm{CeO}_{2}-\mathrm{CrO}_{x}$ catalysts for chlorinated VOCs elimination. Chem. Eng. Sci. 2015, 126, 361-369. [CrossRef]

8. Zhang, Z.; Xia, H.; Dai, Q.; Wang, X. Dichloromethane oxidation over $\mathrm{Fe}_{\mathrm{x}} \mathrm{Zr}_{1-\mathrm{x}}$ oxide catalysts. Appl. Catal. A Gen. 2018, 557, 108-118. [CrossRef]

9. Romero-Sáez, M.; Divakar, D.; Aranzabal, A.; González-Velasco, J.R.; González-Marcos, J.A. Catalytic oxidation of trichloroethylene over Fe-ZSM-5: Influence of the preparation method on the iron species and the catalytic behavior. Appl. Catal. B Environ. 2016, 180, 210-218. [CrossRef] 
10. Su, J.; Liu, Y.; Yao, W.; Wu, Z. Catalytic Combustion of Dichloromethane over HZSM-5-Supported Typical Transition Metal (Cr, Fe, and Cu) Oxide Catalysts: A Stability Study. J. Phys. Chem. C 2016, 120, 18046-18054. [CrossRef]

11. Xingyi, W.; Qian, K.; Dao, L. Catalytic combustion of chlorobenzene over $\mathrm{MnOx}-\mathrm{CeO}_{2}$ mixed oxide catalysts. Appl. Catal. B Environ. 2009, 86, 166-175. [CrossRef]

12. Kan, J.; Deng, L.; Li, B.; Huang, Q.; Zhu, S.; Shen, S.; Chen, Y. Performance of co-doped Mn-Ce catalysts supported on cordierite for low concentration chlorobenzene oxidation. Appl. Catal. A Gen. 2017, 530, $21-29$. [CrossRef]

13. Huang, H.; Zhang, C.; Wang, L.; Li, G.; Song, L.; Li, G.; Tang, S.; Li, X. Promotional effect of HZSM-5 on the catalytic oxidation of toluene over $\mathrm{MnO}_{\mathrm{x}} / \mathrm{HZSM}-5$ catalysts. Catal. Sci. Technol. 2016, 6, 4260-4270. [CrossRef]

14. Jodłowski, P.; Jędrzejczyk, R.; Chlebda, D.; Dziedzicka, A.; Kuterasiński, Ł.; Gancarczyk, A.; Sitarz, M. Non-Noble Metal Oxide Catalysts for Methane Catalytic Combustion: Sonochemical Synthesis and Characterisation. Nanomaterials 2017, 7, 174. [CrossRef]

15. Dai, Y.; Wang, X.; Dai, Q.; Li, D. Effect of Ce and La on the structure and activity of $\mathrm{MnO}_{\mathrm{x}}$ catalyst in catalytic combustion of chlorobenzene. Appl. Catal. B Environ. 2012, 111-112, 141-149. [CrossRef]

16. Yang, P.; Li, J.; Zuo, S. Promoting oxidative activity and stability of $\mathrm{CeO}_{2}$ addition on the $\mathrm{MnO}_{\mathrm{x}}$ modified kaolin-based catalysts for catalytic combustion of benzene. Chem. Eng. Sci. 2017, 162, 218-226. [CrossRef]

17. He, C.; Xu, B.; Shi, J.; Qiao, N.; Hao, Z.; Zhao, J. Catalytic destruction of chlorobenzene over mesoporous $\mathrm{ACeOx}(\mathrm{A}=\mathrm{Co}, \mathrm{Cu}, \mathrm{Fe}, \mathrm{Mn}$, or $\mathrm{Zr}$ ) composites prepared by inorganic metal precursor spontaneous precipitation. Fuel Process. Technol. 2015, 130, 179-187. [CrossRef]

18. Zhao, B.; Li, G.; Ge, C.; Wang, Q.; Zhou, R. Preparation of $\mathrm{Ce}_{0.67} \mathrm{Zr}_{0.33} \mathrm{O}_{2}$ mixed oxides as supports of improved Pd-only three-way catalysts. Appl. Catal. B Environ. 2010, 96, 338-349. [CrossRef]

19. Shen, B.; Wang, Y.; Wang, F.; Liu, T. The effect of Ce-Zr on $\mathrm{NH}_{3}-\mathrm{SCR}$ activity over $\mathrm{MnOx}(0.6) / \mathrm{Ce}_{0.5} \mathrm{Zr}_{0.5} \mathrm{O}_{2}$ at low temperature. Chem. Eng. J. 2014, 236, 171-180. [CrossRef]

20. Azalim, S.; Brahmi, R.; Agunaou, M.; Beaurain, A.; Giraudon, J.M.; Lamonier, J.F. Washcoating of cordierite honeycomb with Ce-Zr-Mn mixed oxides for VOC catalytic oxidation. Chem. Eng. J. 2013, 223, 536-546. [CrossRef]

21. Gutiérrez-Ortiz, J.I.; de Rivas, B.; López-Fonseca, R.; González-Velasco, J.R. Combustion of aliphatic $\mathrm{C}_{2}$ chlorohydrocarbons over ceria-zirconia mixed oxides catalysts. Appl. Catal. A Gen. 2004, 269, 147-155. [CrossRef]

22. De Rivas, B.; López-Fonseca, R.; González-Velasco, J.R.; Gutiérrez-Ortiz, J.I. On the mechanism of the catalytic destruction of 1,2-dichloroethane over Ce/Zr mixed oxide catalysts. J. Mol. Catal. A Chem. 2007, 278, 181-188. [CrossRef]

23. Zhao, C.; Hao, Q.; Zhang, Q.; Yan, N.; Liu, J.; Dou, B.; Bin, F. Catalytic self-sustained combustion of toluene and reaction pathway over $\mathrm{Cu}_{\mathrm{x}} \mathrm{Mn}_{1-\mathrm{x}} \mathrm{Ce}_{0.75} \mathrm{Zr}_{0.25} / \mathrm{TiO}_{2}$ catalysts. Appl. Catal. A Gen. 2019, 569, 66-74. [CrossRef]

24. Deng, L.; Ding, Y.; Duan, B.; Chen, Y.; Li, P.; Zhu, S.; Shen, S. Catalytic deep combustion characteristics of benzene over cobalt doped Mn-Ce solid solution catalysts at lower temperatures. Mol. Catal. 2018, 446, 72-80. [CrossRef]

25. Zhao,H.; Han, W.; Dong, F.; Tang, Z. Highly-efficient catalytic combustion performance of 1,2-dichlorobenzene over mesoporous $\mathrm{TiO}_{2}-\mathrm{SiO}_{2}$ supported CeMn oxides: The effect of acid sites and redox sites. J. Ind. Eng. Chem. 2018, 64, 194-205. [CrossRef]

26. Leng, X.; Zhang, Z.; Li, Y.; Zhang, T.; Ma, S.; Yuan, F.; Niu, X.; Zhu, Y. Excellent low temperature $\mathrm{NH}_{3}-\mathrm{SCR}$ activity over $\mathrm{Mn}_{\mathrm{a}} \mathrm{Ce}_{0.3} \mathrm{TiO}_{\mathrm{x}}(\mathrm{a}=0.1-0.3)$ oxides: Influence of Mn addition. Fuel Process. Technol. 2018, 181, 33-43. [CrossRef]

27. Zhu, B.; Li, X.; Sun, P.; Liu, J.; Ma, X.; Zhu, X.; Zhu, A. A novel process of ozone catalytic oxidation for low concentration formaldehyde removal. Chin. J. Catal. 2017, 38, 1759-1769. [CrossRef]

28. Arena, F. Multipurpose composite $\mathrm{MnCeO}_{\mathrm{x}}$ catalysts for environmental applications. Catal. Sci. Technol. 2014, 4, 189-1898. [CrossRef]

29. Yu, D.; Xingyi, W.; Dao, L.; Qiguang, D. Catalytic combustion of chlorobenzene over Mn-Ce-La-O mixed oxide catalysts. J. Hazard. Mater. 2011, 188, 132-139. [CrossRef] 
30. Tang, A.; Hu, L.; Yang, X.; Jia, Y.; Zhang, Y. Promoting effect of the addition of Ce and Fe on manganese oxide catalyst for 1,2-dichlorobenzene catalytic combustion. Catal. Commun. 2016, 82, 41-45. [CrossRef]

31. He, F.; Luo, J.; Liu, S. Novel metal loaded KIT-6 catalysts and their applications in the catalytic combustion of chlorobenzene. Chem. Eng. J. 2016, 294, 362-370. [CrossRef]

32. Li, J.; Zhao, P.; Liu, S. $\mathrm{SnO}_{\mathrm{x}}-\mathrm{MnO}_{\mathrm{x}}-\mathrm{TiO}_{2}$ catalysts with high resistance to chlorine poisoning for low-temperature chlorobenzene oxidation. Appl. Catal. A Gen. 2014, 482, 363-369. [CrossRef]

33. Venkataswamy, P.; Rao, K.N.; Jampaiah, D.; Reddy, B.M. Nanostructured manganese doped ceria solid solutions for CO oxidation at lower temperatures. Appl. Catal. B Environ. 2015, 162, 122-132. [CrossRef]

34. Chen, H.; Sayari, A.; Adnot, A.; Larachi, F. Composition-activity effects of Mn-Ce-O composites on phenol catalytic wet oxidation. Appl. Catal. B Environ. 2001, 32, 195-204. [CrossRef]

35. Wu, X.; Liang, Q.; Weng, D. Effect of Manganese Doping on Oxygen Storage Capacity of Ceria-Zirconia Mixed Oxides. J. Rare Earths 2006, 24, 549-553. [CrossRef]

36. Trawczyński, J.; Bielak, B.; Miśta, W. Oxidation of ethanol over supported manganese catalysts-Effect of the carrier. Appl. Catal. B Environ. 2005, 55, 277-285. [CrossRef]

37. Zou, Z.; Meng, M.; Zha, Y. Surfactant-Assisted Synthesis, Characterizations, and Catalytic Oxidation Mechanisms of the Mesoporous $\mathrm{MnOx}-\mathrm{CeO}_{2}$ and $\mathrm{Pd} / \mathrm{MnOx}-\mathrm{CeO}_{2}$ Catalysts Used for $\mathrm{CO}$ and $\mathrm{C}_{3} \mathrm{H}_{8}$ Oxidation. J. Phys. Chem. C 2009, 114, 468-477. [CrossRef]

38. Li, H.; Wu, C.; Li, Y.; Zhang, J. $\mathrm{CeO}_{2}-\mathrm{TiO}_{2}$ Catalysts for Catalytic Oxidation of Elemental Mercury in Low-Rank Coal Combustion Flue Gas. Environ. Sci. Technol. 2011, 45, 7394-7400. [CrossRef]

39. Tang, X.; Li, Y.; Huang, X.; Xu, Y.; Zhu, H.; Wang, J.; Shen, W. $\mathrm{MnO}_{\mathbf{x}}-\mathrm{CeO}_{2}$ mixed oxide catalysts for complete oxidation of formaldehyde: Effect of preparation method and calcination temperature. Appl. Catal. B Environ. 2006, 62, 265-273. [CrossRef]

40. Bai, B.; Li, J.; Hao, J. 1D-MnO 2 2D- $\mathrm{MnO}_{2}$ and $3 \mathrm{D}-\mathrm{MnO}_{2}$ for low-temperature oxidation of ethanol. Appl. Catal. B Environ. 2015, 164, 241-250. [CrossRef]

41. Deng, W.; Dai, Q.; Lao, Y.; Shi, B.; Wang, X. Low temperature catalytic combustion of 1,2-dichlorobenzene over $\mathrm{CeO}_{2}-\mathrm{TiO}_{2}$ mixed oxide catalysts. Appl. Catal. B Environ. 2016, 181, 848-861. [CrossRef]

42. Jampaiah, D.; Ippolito, S.J.; Sabri, Y.M.; Tardio, J.; Selvakannan, P.R.; Nafady, A.; Reddy, B.M.; Bhargava, S.K. Ceria-zirconia modified $\mathrm{MnO}_{\mathrm{x}}$ catalysts for gaseous elemental mercury oxidation and adsorption. Catal. Sci. Technol. 2016, 6, 1792-1803. [CrossRef]

43. Cao, F.; Xiang, J.; Su, S.; Wang, P.; Sun, L.; Hu, S.; Lei, S. The activity and characterization of $\mathrm{MnO}_{\mathrm{x}}-\mathrm{CeO}_{2}-\mathrm{ZrO}_{2} / \gamma-\mathrm{Al}_{2} \mathrm{O}_{3}$ catalysts for low temperature selective catalytic reduction of $\mathrm{NO}$ with $\mathrm{NH}_{3}$. Chem. Eng. J. 2014, 243, 347-354. [CrossRef]

44. Ma, C.Y.; Mu, Z.; Li, J.J.; Jin, Y.G.; Cheng, J.; Lu, G.Q.; Hao, Z.P.; Qiao, S.Z. Mesoporous $\mathrm{Co}_{3} \mathrm{O}_{4}$ and $\mathrm{Au} / \mathrm{Co}_{3} \mathrm{O}_{4}$ Catalysts for Low-Temperature Oxidation of Trace Ethylene. J. Am. Chem. Soc. 2010, 132, 2608-2613. [CrossRef] [PubMed]

45. Njagi, E.C.; Genuino, H.C.; King'ondu, C.K.; Dharmarathna, S.; Suib, S.L. Catalytic oxidation of ethylene at low temperatures using porous copper manganese oxides. Appl. Catal. A Gen. 2012, 421-422, 154-160. [CrossRef]

46. Shokouhimehr, M.; Shin, K.; Lee, J.; Hackett, M.; Jun, S.; Oh, M.; Jang, J.; Hyeon, T. Magnetically recyclable core-shell nanocatalysts for efficient heterogeneous oxidation of alcohols. J. Mater. Chem. A 2014, 2, 7593-7599. [CrossRef]

47. Njagi, E.C.; Chen, C.; Genuino, H.; Galindo, H.; Huang, H.; Suib, S.L. Total oxidation of CO at ambient temperature using copper manganese oxide catalysts prepared by a redox method. Appl. Catal. B Environ. 2010, 99, 103-110. [CrossRef]

48. Chen, J.; Chen, X.; Chen, X.; Xu, W.; Xu, Z.; Jia, H.; Chen, J. Homogeneous introduction of CeO $\mathrm{O}_{\mathrm{y}}$ into $\mathrm{MnO}_{\mathrm{x}}$-based catalyst for oxidation of aromatic VOCs. Appl. Catal. B Environ. 2018, 224, 825-835. [CrossRef]

49. Wang, X.; Ran, L.; Dai, Y.; Lu, Y.; Dai, Q. Removal of Cl adsorbed on Mn-Ce-La solid solution catalysts during CVOC combustion. J. Coll. Interf. Sci. 2014, 426, 324-332. [CrossRef]

50. He, C.; Yu, Y.; Shi, J.; Shen, Q.; Chen, J.; Liu, H. Mesostructured Cu-Mn-Ce-O composites with homogeneous bulk composition for chlorobenzene removal: Catalytic performance and microactivation course. Mater. Chem. Phys. 2015, 157, 87-100. [CrossRef]

51. Lu, Y.; Dai, Q.; Wang, X. Catalytic combustion of chlorobenzene on modified $\mathrm{LaMnO}_{3}$ catalysts. Catal. Commun. 2014, 54, 114-117. [CrossRef] 
52. Huang, H.; Gu, Y.; Zhao, J.; Wang, X. Catalytic combustion of chlorobenzene over $\mathrm{VO}_{\mathrm{x}} / \mathrm{CeO}_{2}$ catalysts. J. Catal. 2015, 326, 54-68. [CrossRef]

53. Wu, M.; Wang, X.; Dai, Q.; Li, D. Catalytic combustion of chlorobenzene over $\mathrm{Mn}-\mathrm{Ce} / \mathrm{Al}_{2} \mathrm{O}_{3}$ catalyst promoted by Mg. Catal. Commun. 2010, 11, 1022-1025. [CrossRef]

54. Mao, D.; He, F.; Zhao, P.; Liu, S. Enhancement of resistance to chlorine poisoning of Sn-modified MnCeLa catalysts for chlorobenzene oxidation at low temperature. RSC Adv. 2015, 5, 10040-10047. [CrossRef]

55. Sun, P.; Wang, W.; Dai, X.; Weng, X.; Wu, Z. Mechanism study on catalytic oxidation of chlorobenzene over $\mathrm{Mn}_{\mathrm{x}} \mathrm{Ce}_{1-\mathrm{x}} \mathrm{O}_{2} / \mathrm{H}-\mathrm{ZSM} 5$ catalysts under dry and humid conditions. Appl. Catal. B Environ. 2016, 198, $389-397$. [CrossRef]

56. Hetrick, C.E.; Patcas, F.; Amiridis, M.D. Effect of water on the oxidation of dichlorobenzene over $\mathrm{V}_{2} \mathrm{O}_{5} / \mathrm{TiO}_{2}$ catalysts. Appl. Catal. B Environ. 2011, 101, 622-628. [CrossRef]

57. Shokouhimehr, M.; Kim, T.; Jun, S.; Shin, K.; Jang, Y.; Kim, B.; Kim, J.; Hyeon, T. Magnetically separable carbon nanocomposite catalysts for efficient nitroarene reduction and Suzuki reactions. Appl. Catal. A Gen. 2014, 476, 133-139. [CrossRef]

(C) 2019 by the authors. Licensee MDPI, Basel, Switzerland. This article is an open access article distributed under the terms and conditions of the Creative Commons Attribution (CC BY) license (http://creativecommons.org/licenses/by/4.0/). 